\title{
Health and the Political Agency of Women
}

\author{
By Sonia Bhalotra And Irma Clots-Figueras*
}

\begin{abstract}
We investigate whether women's political representation in state legislatures improves public provision of antenatal and childhood health services in the districts from which they are elected, arguing that the costs of poor services in this domain fall disproportionately upon women. Using large representative data samples from India and accounting for potential endogeneity of politician gender and the sample composition of births, we find that a 10 percentage point increase in women's representation results in a 2.1 percentage point reduction in neonatal mortality, and we elucidate mechanisms. Women's political representation may be an underutilized tool for addressing health in developing countries. (JEL D72, I12, I15, J16, O15, O17)
\end{abstract}

\section{Motivation and Summary}

This paper investigates the political economy of public health provision, focusing upon the relevance of political identity and, in particular, the gender of politicians. The widespread failure of public health provision in developing countries is commanding increasing attention in the global arena (Black, Morris, and Bryce 2003) and in India (Chaudhury et al. 2006; Das Gupta 2005; Muralidharan et al. 2011). Poverty is not a compelling explanation for the scale of (maternal and) child death given that most deaths can be averted with low cost interventions (Cutler, Deaton and Lleras-Muney 2006). The evidence points to political failure (Kiefer and Khemani 2003; Besley and Kudamatsu 2006) but the idea that public health services may suffer from the underrepresentation of women in government has not received dedicated consideration. In our sample, in India, 10 percent of children die before the age of one and less than 4 percent of state legislators are women. We investigate whether these phenomena are causally related

Preference differences between the sexes identified in numerous settings suggest that women are more likely than men to (i) invest in children and (ii) favor

\footnotetext{
* Bhalotra: Department of Economics, University of Essex, Wivenhoe Park, Colchester, Essex CO4 3SQ, UK and the Institute for Social and Economic Research (e-mail: srbhal@essex.ac.uk); Clots-Figueras: Universidad Carlos III de Madrid, Departamento de Economía, calle Madrid 126, 28903 Getafe Madrid, (Spain) (e-mail: iclots@eco.uc3m.es, irmaclots@gmail.com). We benefited from presenting this paper at the American Economic Association meetings, the Workshop on Gender Economics (FEDEA), a CEPR/BREAD/AMID conference in London, the NEUDC, the Indian Statistical Institute Delhi, the Public Health Foundation Delhi, the University of Oxford, NHH Bergen and the University of Goettingen. We would like to thank Lakshmi Iyer for providing the data on the gender of state chief ministers and Steve Bond, Martin Browning, Lakshmi Iyer, Stephan Klasen, Kate Vyborny, and two referees for helpful comments.

${ }^{\dagger}$ Go to http://dx.doi.org/10.1257/pol.6.2.164 to visit the article page for additional materials and author disclosure statement(s) or to comment in the online discussion forum.
} 
redistribution. 1 This suggests that women may be more likely to deliver public health improvements in developing countries because there are sharp positive age and income gradients in health and the essential policy challenge lies in addressing the early life health and survival of children in poor families. ${ }^{2}$ Moreover, the benefits of interventions in this area flow differentially to women because they disproportionately bear the costs of weak reproductive and child health services. Women carry the burden of high fertility and child mortality: they care for the sick, witness their children die, have further births, and risk dying in childbirth. ${ }^{3}$ In line with our hypothesis, the enfranchisement of women in early twentieth century America led to a sharp rise in state health expenditure and a steep drop in infant mortality (Miller 2008). And results of the British Election Survey of 2001 show that the single most important concern for men is low taxes while, for women, it is the quality of the National Health Service (Campbell 2004). ${ }^{4}$

We investigate whether women's political representation in state legislatures in India influences policy outcomes for individuals in the districts from which they are elected. Data on health outcomes, health-related behaviors, and village-level access to health facilities for a large representative sample of individuals are matched to the gender composition of state legislators around the time of their birth and in the district of their birth. The main identification challenge is that the gender of a competitively elected leader is likely to be correlated with voter preferences and hence endogenous. A second potential source of bias is that the composition of births is endogenous to the political regime. We address these problems using a fixed effects instrumental variables estimator that exploits constituency-level information on close elections between men and women on the one hand, and information on siblings in a large sample survey on the other. We test our identifying assumptions.

Consider the size of the estimated impacts on neonatal and infant mortality, which are markers of the state of public health in developing countries. We find that a one standard deviation increase in women's political representation in the birth year (and similarly in the two years preceding birth) results in a 1.5 percentage point ( 24 percent) reduction in neonatal mortality, which is a 0.06 standard deviation change. An alternative expression of effect sizes is that a 10 percentage point increase in the share of women elected from the index district to state assembly

\footnotetext{
${ }^{1}$ On (i), see Thomas 1990; Thomas and Welch 1991; Hoddinott and Haddad 1995; Lundberg, Pollak, and Wales 1997; Case 1998; Svaleryd 2002; Besley and Case 2003. One possible explanation of this is paternity uncertainty (Alexander 1974). On (ii), see Besley and Case 2000; Andreoni and Vesterlund 2001; Edlund and Pande 2002; Edlund, Haider, and Pande 2005; Warner and Steel 1999; Washington 2008; Oswald and Powdthavee 2010. This has been linked to women being, on average, less likely to pay taxes and more likely to receive benefits (e.g., Alessina and La Ferrara 2005).

${ }^{2}$ Early childhood death accounts for 30 percent of all deaths in poor countries compared with 1 percent in richer countries (Cutler et al. 2007). There are vast inequalities in health within poor countries and most childhood deaths occur in poor households.

${ }^{3}$ In the sample period, almost one in ten children died in India before the age of one. Structural estimates on data from the Indian state of Uttar Pradesh indicate that for every neonatal death (which we analyze here), women have an additional 0.37 births (Bhalotra and van Soest 2008). Maternal mortality as a fraction of births is estimated at 0.5 percent (UNICEF).

${ }^{4}$ At the turn of the century, fertility and infant mortality rates in America were similar to those in our estimation sample for India. In Britain in 2001, both were dramatically smaller. Even so, most women expect to engage with public health services at least once through pregnancy and this makes them heavier users, other conditions equal. The greater concern of women for public health in contemporary Britain may also reflect their representation of children and of the poor.
} 
seats results in a 2.1 percentage point (33.5 percent) reduction in neonatal mortality. A 10 percentage point increase in women's representation is close to a shift from zero to one woman in the median district in our sample, which has nine seats. The estimated changes in neonatal mortality drive similarly large impacts on infant mortality. To put the effect size in perspective, note that the causal impact of democratization on infant mortality in sub-Saharan Africa in the post-Cold War period is estimated to be a 1.2 percentage point drop in infant mortality, which is 12 percent of the sample mean (Kudamatsu 2012).

We find limited evidence of "elitism" amongst women elected to state legislatures. For instance, the point estimates suggest larger impacts for low-caste children and amongst children of families in the middle as compared with the top of the wealth distribution. There are no significant differences in the impact of women politicians who belong to lower vs higher castes. These results are topical given that a bill proposing quotas for women in state assemblies is currently pending in the Indian Parliament, with one of the axis of debate being that women elected to state assemblies are unlikely to represent the interests of the poor (Rai 2002; Section II below).

We show that a number of constituency and candidate characteristics are uncorrelated with the gender of the winner in the close election sample and the estimates stand up to a battery of checks including variation of the vote margin that identifies close elections and controls for party and a polynomial in the vote margin. They are robust to a rich set of controls for within-mother and district-level unobservable trends, and to three falsifying tests. We report several extensions, looking at the impacts of decentralisation, political competition, turnout, media activity and party alignment. We find no evidence that devolutionary reforms in 1993, resulted in power being devolved to district and village councils, weakened the influence of women in state assemblies. The relative influence of women in state legislatures is greater when the chief minister is a woman. However, belonging to the same party as the chief minister does not enhance the influence of women legislators, which supports our identification of gender as distinct from party effects. ${ }^{5}$

We are able to identify mechanisms, and this underlines the plausibility of our findings. We find that women politicians are more likely to invest in the village level public health infrastructure while men appear more likely to invest in the financial (and telecommunications) infrastructure. Raising female political representation results in substantially improved probabilities of attending antenatal care, taking iron supplements during pregnancy, giving birth in a government facility as opposed to at home (note: we establish no change in the probability of giving birth in a private facility), and early initiation of breastfeeding. By analyzing outcomes such as breastfeeding that are not dependent upon infrastructure, we argue that the evidence is also consistent with politician-led information campaigns. Our finding that the estimated impacts are larger for first-births also suggests a role for information as information obtained for a first birth tends to persist within mother.

Our results resonate with a literature which suggests that women exhibit a stronger propensity to invest in children and have more progressive social preferences

\footnotetext{
${ }^{5}$ The point estimates indicate that turnout and newspaper circulation in the regional language enhance the policy influence of women while party competition tends to lower it but these estimates are imprecise.
} 
than men. Possibly our main contribution is to the literature describing persistence of an unnecessarily large global disease burden and, in this context, the failure of public health delivery. We propose reasons that women will tend to have stronger preferences over health provision than men and produce robust estimates of causal effects using several large representative samples of data from India. Our finding that incremental changes in women's representation in state assemblies have sizeable impacts on health-related infrastructure, behavior and outcomes is of potential policy significance not only in relation to motivating political quotas but also insofar as it extends our understanding of how political improvements in public health may be achieved.

\section{Women in Politics: Theoretical Background and Evidence}

In the benchmark model of democracy, characterized by complete policy commitment, policy choices reflect voter preferences and are independent of legislator identity (Downs 1957). However, more recent citizen candidate models admit a role for legislator preferences (Besley and Coate 1997; Levitt 1996; Osborne and Slivinski 1996). This introduces the possibility that women politicians make different policy choices than men but this rests upon women having different preferences from men. In this way, this paper binds two streams of the literature, one concerned with political identity and the other with differences in preferences between the sexes. We have identified public health as a domain over which we expect women have stronger preferences. Identifying the empirical relevance of preference differences and the domains in which they are most active is key to informing debates over quotas for women in government, debates which refer not only to representation but also to principles of fairness and diversity (Squires 1996), and which suffer from a scarcity of causal evidence of the impact of representation on policy outcomes.

Much of the recent evidence in economics on the influence of women in government has emerged from India following a constitutional amendment which came into force in 1993, and after which the federal government devolved power to district and village level governments and introduced reservations for women at these levels. In particular, it was mandated that a third of the seats in every village council and, by random assignment, a third of the posts of head of village council be reserved for women. A recent crop of studies analyzes policy and process in village-level governance after 1993, comparing villages in which council headship was reserved for women with villages in which it was not (Duflo and Chattopadhyay 2004; Beaman et al. 2007, 2009; Deininger, Jin, and Nagarajan 2011; Iyer et al. 2011). Since every village had a third of its seats reserved for women after the amendment, these post-1993 cross-village comparisons identify the impact of council headship rather than women's representation. ${ }^{6}$

\footnotetext{
${ }^{6}$ An exception is Iyer et al. (2012) who analyze the combined influence of reservation of headship and of a third of the seats of the village council for women. Rather than a cross-village comparison of local outcomes they study cross-state variation in the reporting of crimes against women as a function of variation in the year in which different states implemented the 1993 village-level reform.
} 
Our analysis of women's representation in state legislative assemblies is moot given that a Women's Reservation Bill proposing that a third of seats in state assemblies and parliament be reserved for women is currently under debate. The Bill was introduced in September 1996 and passed by the Rajya Sabha (Upper House) in March 2010 but is currently pending in the Lok Sabha (Lower House). The introduction of reservations for women in village councils in 1993 is regarded as a victory for India's women's movement as it allowed the grassroots involvement of village women in village-level development programs. The more limited support for the move to introduce reservations in state and national parliaments reflects, in part, a concern that women who claim those seats will tend to be elite and therefore unlikely to represent the interests of the majority of women citizens (Mishra 2000, Rai 2002). By studying child mortality, which is most prevalent among the poor, we effectively test the hypothesis that the policy choices of women in state assemblies are detached from the interests of the common woman.

We differ from most previous work in studying women politicians in state legislatures rather than village councils, acting as members [of the state legislature] rather than as heads [of the village council] and elected against men rather than appointed to reserved seats. ${ }^{7}$ Women in India occupy a small share of state assembly seats and it is conceivable that incremental changes in their share will have limited policy influence even if their headship at the local level counts. In contrast to previous studies, we investigate not only the composition of village level public goods but, by studying health outcomes, we also study the effectiveness of state interventions. We analyze a longer period of India's democratic history that includes pre-1993 data. This allows us to test whether the devolutionary reforms in 1993, by sharing power with district and village councils, weakened the influence of women in state assemblies. This is the first paper to investigate whether women's say varies with indicators of political competition, and with the gender and party similarity of the state chief minister. Alongside a range of indicators of public health, we investigate fertility and the sex of births as outcomes.

Two previous studies investigate the role of women in state legislatures. One concludes that raising the share of female politicians results in higher education but only in urban areas (Clots-Figueras 2012). The other finds improvements in a wider set of policy variables but shows that these improvements flow essentially from women who hold seats reserved for the lower castes, that is, from "nonelite" women politicians (Clots-Figueras 2011). However it looks at law, expenditure, and infrastructure aggregated to the state-level and it may be that the influence of higher caste women is apparent at a more disaggregate level, in the allocation of resources towards their constituencies. Alternatively, their influence may lie not in expenditure and infrastructure but in the effectiveness of provision arising, for example, from the conduct of information campaigns. We therefore look at effectiveness of politicians at the local level and motivate a focus on public health provision as a domain

\footnotetext{
${ }^{7}$ While randomization of the headship of the village council in India created quasi-experimental data, a limitation of generalizing results from analysis of reservations is that they can have direct effects on policy outcomes by changing the nature of political competition (Franceschet, Krook, and Piscopo 2012). We discuss identification of the influence of competitively elected leaders in Section IV.
} 
in which gendered preferences may be exhibited and also a domain in which the beneficiaries are relatively poor.

\section{Data and Descriptive Statistics}

Health Outcomes and Facilities.-We avoid the use of state-level health expenditure given that its effectiveness in developing countries at large has been debated (Filmer and Pritchett 1999; Filmer, Hammer, and Pritchett 2000). Raising the share of women in US state legislatures has been shown to raise state health spending (Rehavi 2003) but, in India, a disproportionate share of the health budget is dedicated to (curative) hospital services which are less pro-poor than (preventive) public health expenditures (Peters et al. 2002). While Indian data suggest some impact of health expenditure on infant mortality, this impact is weakest in the most vulnerable groups (Bhalotra 2007). We select neonatal and infant mortality as indicators of public health provision that measure the effectiveness of state intervention, and at a local level, namely, the district from which the politician is elected. To investigate what it is that women politicians actually do, we investigate the influence of politician gender on the village level public health infrastructure. However public health facilities in India are often poorly staffed (Das and Hammer 2007; Banerjee, Deaton, and Duflo 2003) and uptake of publicly provided services such as immunization low (Banerjee et al. 2010). So we also investigate a range of indicators of the utilization of publicly provided antenatal and early postnatal care to indicate whether politician gender influences health-seeking behavior. There is a sharp wealth gradient in all of the outcomes.

Health Data.-Individual data on child survival are obtained from retrospective fertility histories reported in the second round of the Indian National Family Health Survey (NFHS) by a representative sample of ever-married women aged 15-49 in 1998-1999. ${ }^{8}$ This makes it straightforward to identify siblings. There is an average of 3.8 births per mother, conditional on at least two. The histories provide information on the year of birth and death for births that occur across three decades, so these data can be matched to the time variation in the political data. The data indicate the district of current residence and the years that the mother has lived in her current location. We drop mothers who had births in a location other than the current residence, but we investigate this restriction below. To allow for full exposure to neonatal [infant] morality risk we exclude children born less than a month [a year] before the date of the survey. We also draw from the NFHS information on health-seeking behaviors in the four years preceding the survey date and on village facilities at the time of the survey. These are defined in the Data Appendix and discussed further in the results section. The state of public health is very poor. For instance, in our sample period, 10 percent of children die before the age of one, almost 70 percent of births occur at home and only 14 percent of villages have a primary health center. All descriptive statistics are in Tables $1 \mathrm{~A}, 1 \mathrm{~B}$, and $1 \mathrm{C}$.

\footnotetext{
${ }^{8}$ For further information, including sampling design, see International Institute for Population Sciences and ORC Macro (2000). For a discussion of the potential issues arising with the use of retrospective data, see the Data Appendix.
} 
TABLE 1A-Descriptives

\begin{tabular}{lcc}
\hline \hline & Mean & SD \\
\hline Unit of observation: Individual (child), cohorts 1968-1999 in 246 districts & & 0.2423 \\
Neonatal mortality & 0.0627 & 0.2973 \\
Infant mortality & 2.7561 & 1.8099 \\
Birth order & 0.0138 & 0.1166 \\
Multiple birth & 0.4770 & 0.4995 \\
Girl & 0.1959 & 0.3969 \\
Scheduled Caste (SC) & 0.1080 & 0.3104 \\
Scheduled Tribe (ST) & 0.1070 & 0.3092 \\
Muslim & 0.0113 & 0.1057 \\
Christian & 0.0332 & 0.1791 \\
Other religion & 0.7816 & 0.4131 \\
Rural & 22.7412 & 5.0420 \\
Age of the mother at birth & 75,339 & \\
Observations & & \\
& & 2.4403 \\
Unit of observation: Individual (child) in the four years before the survey date (1998-1999) & 2.3190 & 0.4617 \\
Number of antenatal visits & 0.6920 \\
Delivery at home & 0.1618 & 0.3683 \\
Delivery in a government institution & 0.1462 & 0.3533 \\
Delivery in a private institution & 0.4816 & 0.4997 \\
Breastfed in the first 24 hours & 0.5714 & 0.4949 \\
Took iron and folic acid supplements during pregnancy & 0.7361 & 0.4408 \\
Received a tetanus injection during pregnancy & 8,853 & \\
Observations & & \\
\hline
\end{tabular}

Notes: National Family Health Survey, Round 2 (1998-2000), summary statistics for estimation samples. The sample used to estimate childhood mortality outcomes consists of 75,339 children born in 1968-1999 across 246 districts. The sample used to estimate health-seeking behaviors consists of 8,853 children born in the four years before the survey date. "SD" is standard deviation.

Political Structure.-India is the largest and oldest democracy in the developing world. It has a federal structure in which the constitution devolves significant control over their own government to the 28 states and 7 union territories, and population health falls under the purview of State Legislative Assemblies. States and union territories are divided into single-member constituencies in which candidates are elected in first-past-the-post elections. The boundaries of assembly constituencies are drawn to make sure that there are, as near as practicable, the same number of inhabitants in each constituency. Thus, state assemblies vary in size with the state population. Districts are an important level of local government between state and village governments. Most decisions pertaining to public health provision were made at the state level until 1993 (Rao and Singh 1998). Even after 1993, when powers over the implementation of developmental projects were devolved to the district and village level, state legislators continued to have substantial say and to play a potentially important role in negotiation with and coordination across layers of local government.

Electoral Data.-We have constituency-level data on the gender and votes won by the winner and runner-up for every election to State Legislatures in India during 1967-1998. Our sample contains information on 76,732 constituency elections in the 16 larger states. In order to match these data with health data, they are aggregated to the district level (see the Data Appendix). Districts have between 1 and 37 electoral constituencies and the median district has 9. Elections are routinely 
Unit of observation: District in an electoral year, elections between 1967-1998 in 246 districts

Proportion of seats won by women (women)

$0.0364 \quad 0.0740$

Proportion of districts that had at least one woman politician

Proportion of seats that had close elections between women and men, close:

0.2640

0.0333 3.5 percent margin (totalclose)

Proportion of districts that had at least one election between a woman and a man

0.0084

0.4905

Proportion of districts that had at least one close election between a woman and

0.4025

0.2626 a man (3.5 percent)

Proportion of seats won by women in close elections against men (3.5 percent)

0.0745

0.0227 (womenclose)

Proportion of districts that had at least one woman politician who won in a close

0.0041

0.1921 election against a man ( 3.5 percent $)$

Dummy for the first election between a woman and a man $\left(I_{j}\right)^{*}$

0.0383

0.192

Dummy for the second election between a woman and a man

Dummy for the third election between a woman and a man

0.1292

0.3356

Dummy for the fourth election between a woman and a man

0.0389

0.1934

Dummy for the fifth election between a woman and a man

0.0071

0.0841

Dummy for the sixth election between a woman and a man

$0.0044 \quad 0.0661$

Vote margin for the first election between a woman and a man $\left(m_{j}\right)^{\text {*** }}$

0.0331

Vote margin for the second election between a woman and a man

0.0011

0.1820

Vote margin for the third election between a woman and a man

0.0142

0.2499

Vote margin for the fourth election between a woman and a man

0.0307

0.3002

Vote margin for the fifth election between a woman and a man

0.0024

0.3105

Vote margin for the sixth election between a woman and a man

0.0115

0.3827

$-0.0241$

0.4649

Proportion of seats reserved for SC/ST candidates

0.2366

0.1785

Proportion of seats won by Congress parties

0.4519

0.3317

Proportion of seats won by Hard Left parties

0.0589

0.1512

Proportion of seats won by Soft Left parties

0.0231

0.0901

Proportion of seats won by Janata parties

0.1661

0.2727

Proportion of seats won by Hindu parties

0.1280

0.2290

Proportion of seats won by Regional parties

0.0772

0.2027

Female literacy rate

0.2844

0.1720

Male literacy rate

0.5352

0.1559

Proportion of SC/STs

0.2524

0.1344

Proportion of urban population

0.2041

0.1409

Proportion of female population

0.4811

0.0167

Women belonging to the same party of the chief minister

0.0146

0.0505

$0.0218 \quad 0.0570$

Political Competition Index (Besley and Burgess 2002)

$-0.4446$

0.2105

Turnout rate

59.1858

9.5442

Female turnout rate

Female to male turnout ratio

Newspaper circulation (Besley and Burgess 2002)

53.6500

11.5700

0.8387

0.0876

$0.0599 \quad 0.0400$

Newspaper circulation (Besley and Burgess 2002) English

0.0085

0.0141

Newspaper circulation (Besley and Burgess 2002) Hindi

0.0251

Newspaper circulation (Besley and Burgess 2002) Regional languages

0.0234

0.0342

Whether state chief minister is a woman

0.0519

0.0356

0.1353

Observations

1,826

Notes: Electoral data from the Election Commission of India was obtained at the constituency level and aggregated to the district level. Summary statistics for the estimation sample. Individual health outcomes are matched to politician gender in their district of birth in the year before their birth, hence the one year difference in the year range between the health and electoral sample.

*The first, second, etc. elections refer to the number of constituencies within a district that have a man-woman election. So 40 percent of districts have at least one constituency (seat) that was won in a man-woman election, 13 percent of districts have at least two, and so on.

**The vote margins are ordered by absolute value in districts with more than one election and now first, second, etc. margin refer to the first, second, etc. constituency. 
TABLE 1C-Descriptives

\begin{tabular}{lcc}
\hline \hline Unit of observation: Village & Mean & SD \\
\hline Primary health subcenter & 0.3517 & 0.4777 \\
Primary health center & 0.1418 & 0.3490 \\
Community health center & 0.0815 & 0.2737 \\
Government dispensary & 0.1252 & 0.3310 \\
Government hospital & 0.0353 & 0.1846 \\
Electricity & 2.1797 & 0.6976 \\
Post office & 0.3755 & 0.4844 \\
Telegraph & 0.2015 & 0.4013 \\
STD (telephone) booth & 0.1958 & 0.3969 \\
Bank & 0.2831 & 0.4506 \\
Observations & & \\
\hline
\end{tabular}

Notes: Data from the village file of the National Family Health Survey, 1988-1999, containing information on facilities at the time of the survey. Summary statistics for the estimation sample for the infrastructure equations.

every five years but states often hold mid-term elections at shorter intervals. The mean proportion of seats in a district won by women is 3.6 percent (SD 7.4 percent). The median is zero and the seventy-fifth and ninetieth percentiles are, respectively, 5.5 and 14.3 percent. So the distribution is highly skewed (Figure A1 in the online Appendix). At least one woman was elected in 26.4 percent of district-electoral years and in this subsample, the share of seats held by women is 13.8 percent. There is an upward trend in the share of seats held by women (Figure 1) and substantial differences in both the level and trend by state (Figure 2).

We define close elections as elections in which the winner and the runner-up are of opposite gender and the vote margin between them is less than 3.5 percent. Across the sample period, only 7.45 percent of district-years had at least one close election, but they have become more common over time. Fewer than 1 in 400 seats had close elections between women and men in the 1960s and 1970s, and that figure jumped to more than 1 in 100 for the 1980s and 1990s.

Merged Data.- The health data are merged with the political data by district and (lagged) birth year to produce a micro panel of births within mother nested within a district-year panel. The estimation sample contains more than 70,000 individual births to some 18,000 mothers that occur across 246 districts (in 16 states) over the 32-year period, 1967-1998. 9 A nonparametric (lowess) plot of the relationship between neonatal mortality risk and the share of women leaders at the district level shows that the unconditional relationship is negative (Figure A2 in the online Appendix). We now investigate whether a negative relationship persists after allowing for endogeneity and heterogeneity.

\footnotetext{
${ }^{9}$ The number of election years is 26 and, since different states had elections in different years, the estimation sample contains 1,826 district-year cells.
} 


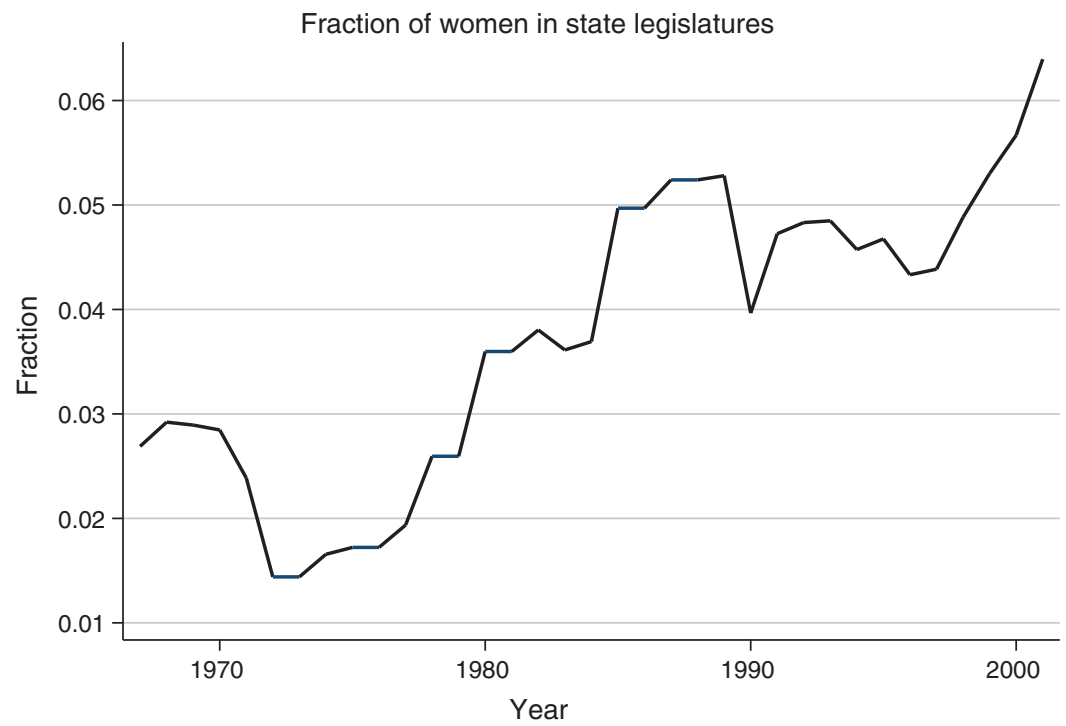

Figure 1. Female Political Representation: All India

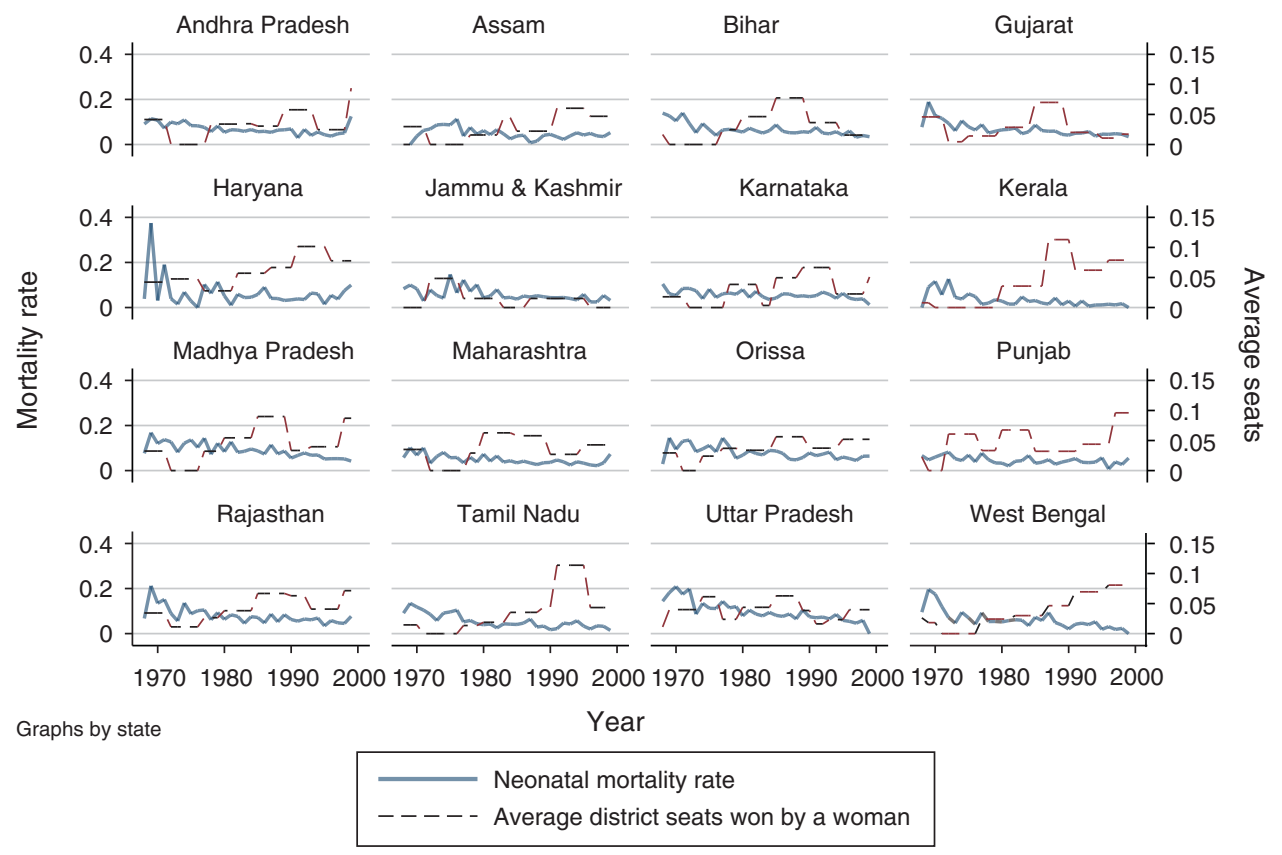

Figure 2. Female Political Representation and Neonatal Mortality by State

\section{Empirical Strategy}

We are interested in the relationship between an individual's access to public health services and the share of women elected to state assemblies from the individual's district of birth. We focus upon antenatal and early postnatal services targeted 
at women and newborns, and hence at the gender mix of politicians in the year before and the year of birth. In this section, we explain how we address the three potential sources of bias that arise. First, women's representation tends to be correlated with voter preferences. Second, the composition of births may vary endogenously. Third, there may be district-year varying changes in other determinants of health that coincide with the election of women.

To address the problem that common unobservables may drive both electoral preferences for women and health-related behaviors we instrument the overall share of women politicians with the share of women who win in close elections against men. Close elections are defined as those in which the winner and the runner up are of opposite gender and the margin of victory is small. The premise is that the identity (gender) of the winner of a close election is quasi-random. To see this, note that in a first-past-the-post electoral system, the probability of being elected is a function of the vote difference between the winner and the runner-up and this function has a discontinuity at zero. As the vote difference approaches the discontinuity, constituencies in which a woman wins by a small vote margin are increasingly similar to constituencies in which a man wins by a small margin (Lee 2001; Pettersson-Lidbom 2001). Since we aggregate to the district level over discontinuities at the constituency level, our specification is similar to a fuzzy regression discontinuity design (e.g., Angrist and Pischke 2008, 259). We investigate robustness of the estimates to controls for varying polynomials in the constituency-specific margins of victory or defeat of each man-woman close election in the district.

The identification driving our approach is nicely illustrated in Figure 3, which plots the fraction of seats (constituencies) in the district won by female politicians against the margin of victory between the female and the male candidate (a positive margin means that the woman won). Figure 3, panel A uses all the elections between a male and a female politician, while Figure 3, panel B restricts the sample to those districts that had a single election between a male and a female politician. The data are aggregated into one percentage point bins, as suggested by Imbens and Lemieux (2008), and we plot a lowess smoothing line on each side of the discontinuity. The size of the jump in Figure 3, panel A indicates that a woman winning a close election in a district increases the fraction of constituencies in the district won by female politicians by roughly 10 percentage points. This is what we would expect given that the average district has 9-10 constituencies.

Although the gender of the winner in a close election may be considered random, the existence of close elections between women and men may not, for example, it may depend on the number of female candidates in the district and this, in turn, may be correlated with voter preferences. To allow for this, we control for the fraction of seats in the district that had close elections between female and male candidates in the first and second stage of the instrumental variables procedure. Close elections between women and men have been previously used for identification by Rehavi (2003) and Clots-Figueras $(2011,2012)$. We investigate the assumptions underlying the use of close elections in Section VB, where we also assess the external validity of our estimates.

Since we focus upon newborns, we need to address a further potential source of bias arising from endogenous heterogeneity in the timing of fertility: through 


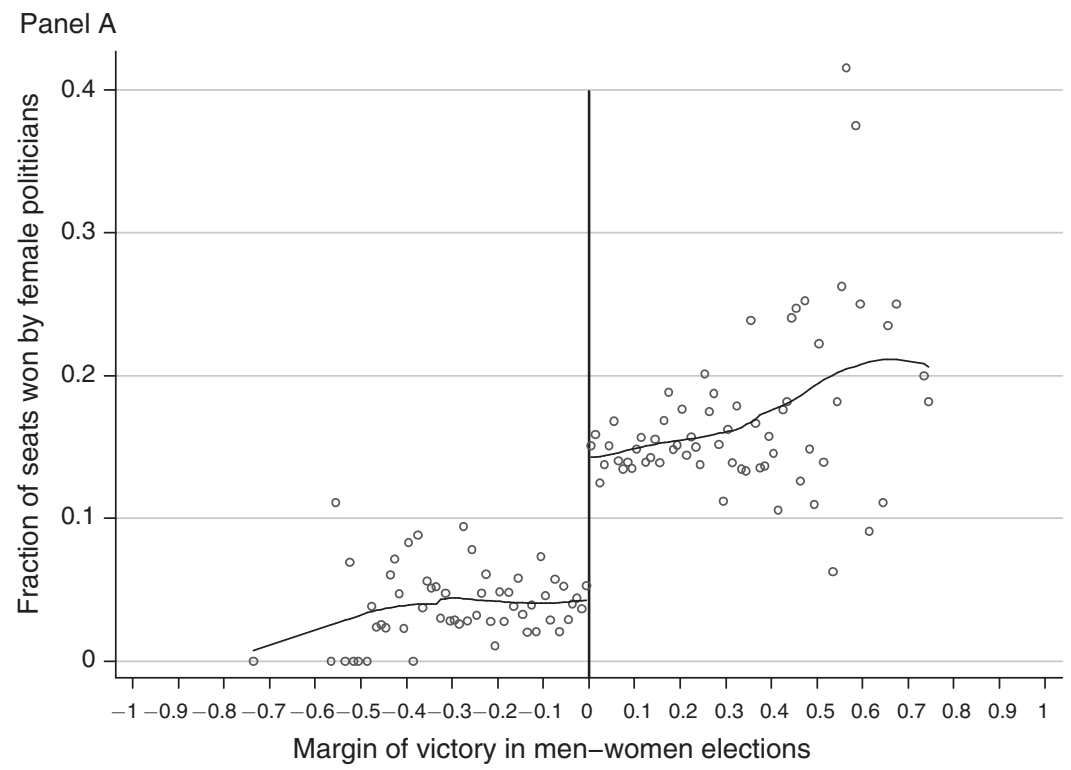

Panel B

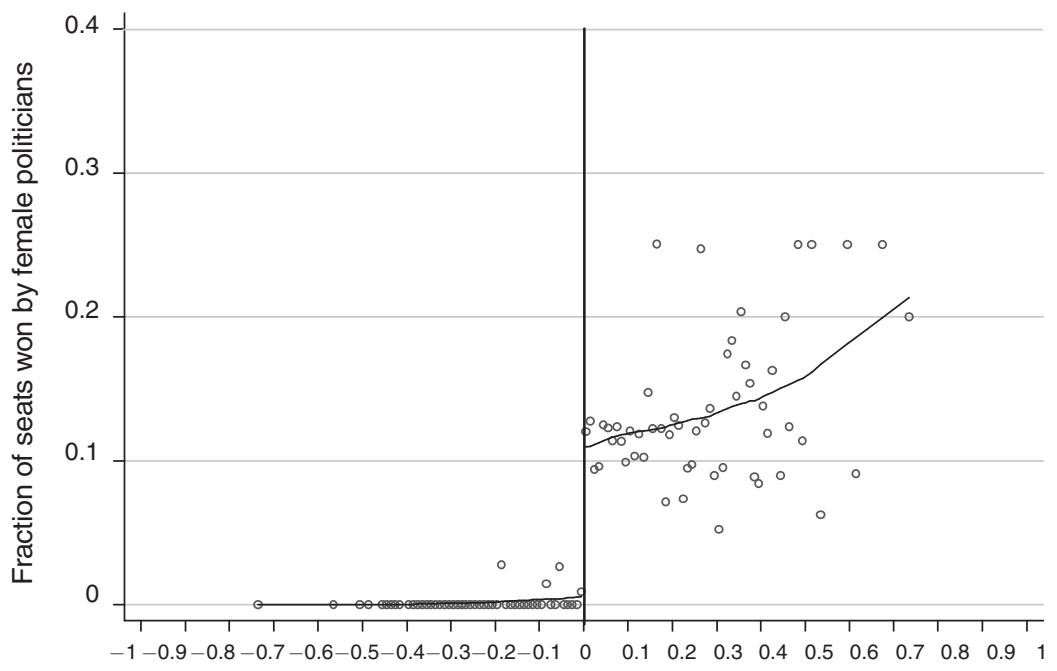

Margin of victory in men-women elections

Figure 3. First Stage Illustration

Note: We plot the fraction of seats won by female politicians against the margin of victory in elections between women and men. Figure 3, panel A uses all the elections between a male and a female politician, while Figure 3, panel B restricts the sample to those districts that had a single election between a male and a female politician.

selection into either conception or fetal survival, the composition of live births in the sample may vary systematically with the gender composition of politicians. ${ }^{10}$ For instance, some women may be more likely than others to consciously advance or

${ }^{10}$ See Dehejia and Lleras-Muney (2004) and Bhalotra (2010) who argue that selection may arise from the conscious timing of fertility and the selective survival of the fetus respectively. 
defer fertility in response to the policy [political] regime. Alternatively, fetal death (whether through miscarriage or (female) feticide), may vary systematically as a function of reproductive health facilities and campaigns discouraging feticide and these facilities and campaigns may in turn be influenced by the share of women politicians. If, for instance, the incidence of female feticide declines under women politicians then, given that feticide is more common amongst educated mothers (Bhalotra and Cochrane 2010), the composition of (live) births that we observe under women politicians will tend to be lower risk than the sample observed under male politicians. If we do not control for this, we may attribute what is essentially a selection effect to differences in the behavior of female versus male politicians. We limit this problem by using mother fixed effects. These will purge all fixed mother-level unobservables including the time-invariant component of their political preferences and any tendency they may have to compensate or reinforce state investments in children (crowding out or crowding in). This is a considerable improvement relative to using district fixed effects.

The third potential bias is addressed by controlling for unobservable trends. In the specification illustrated below, we control for state-specific trends but in extensions of this we demonstrate robustness to district-specific trends and district by mother-cohort fixed effects. The first set of estimated models is

$$
\begin{aligned}
\text { (1) } \text { mortality }_{\text {imdt }}= & \alpha_{m}+\theta_{t}+\beta \text { women }_{d t-1}+\sum_{j=1}^{N} \partial_{1 j} I_{j d t} \times F\left(m_{j d t}\right)+\sum_{j=1}^{N} \partial_{2 j} I_{j d t} \\
& + \text { totalclose }_{d t-1}+\mathbf{X}_{\text {imdt }} \zeta+\cdots+\mathbf{Z}_{d t} \mu+\varphi_{s} t+\varepsilon_{\text {imdt }}
\end{aligned}
$$

(2) women $_{d t}=\chi_{m}+\omega_{t}+\tau$ womenclose $_{d t}+\sum_{j=1}^{N} \partial_{3 j} I_{j d t} \times F\left(m_{j d t}\right)$

$$
+\sum_{j=1}^{N} \partial_{4} I_{j d t}+\psi \text { totalclose }_{d t}+\cdots+\mathbf{X}_{\text {imdt }} \rho+\mathbf{Z}_{d t} \pi+\boldsymbol{v}_{s} t+e_{i m d t} .
$$

The subscripts denote the individual child $i$ of mother $m$ born in district $d$ (in state $s$ ) in year $t$. By construction, mothers do not migrate across districts between births (we investigate this restriction in Section VB). Hence mother fixed effects nest (or imply) district fixed effects. Mortality is an indicator for the index child dying by the age of one month (neonatal), women is the district-level share of state assembly constituencies to which a woman was elected in the year before the child was born (we investigate timing below) and $\beta$ is the parameter of interest. The other variables in equation (1), in order, are mother and (child) cohort fixed effects, a third-order polynomial $(F)$ in the victory margin $(m)$ between the winner and the runner up for every (close or nonclose) man-woman election $j$, interacted with $I_{j d t}$, an indicator for whether such an election exists, totalclose is the fraction of constituencies in the district that experienced a close election, $\mathbf{X}$ is a vector of child or mother-specific controls, $\mathbf{Z}$ is a vector of district-year varying controls and $\varphi$ are state-specific trends. We examine sensitivity to the definition of close elections, inclusion of victory margins, district trends, flexible trends in mother's age and cohort, and individual controls. 
Equation (2) represents the first stage of the IV procedure. It shows the potentially endogenous regressor, women, regressed upon the instrument, womenclose, and the same set of controls. The instrument is the fraction of constituencies in the district in which a woman won against a man in a close election.

The cohort dummies control for aggregate time variation associated with, for example, secular improvements in health technology, episodic shocks like famines, floods and epidemics and any aggregate economic or political regime changes. The state (and, later, district) specific trends allow for regional omitted trends, for example, income or trends in the status of women. The district level controls $\mathbf{Z}$ include the shares of the population that are female, urban, and low caste as well as male and female literacy rates. Controls $\mathbf{X}$ include dummies for the gender, birth order, rural/urban location, religion, and caste of the child and an indicator for whether the child is one of a multiple birth.

We use a linear model since fixed effects probit estimates are inconsistent in short panels (Nickell 1981) and the relevant panel in this case is the micro-panel, where $T$ is the number of children per mother. Standard errors are robust to arbitrary forms of heteroskedasticity and clustered at the district-level since the regressor of interest, women, is entered as a district-level share. This allows for correlations at any time and across time within district (e.g., Bertrand, Duflo, and Mullainathan 2004). It also allows for correlation of the standard errors across siblings because, by construction, siblings are all in the same district.

In sum, the estimated specification delivers an estimate of the difference in mortality risk across children of the same mother born at different times and under different political regimes, with the change in political regime constructed as a quasi-random assignment of the gender of politicians in the district of birth. We investigate the identifying assumptions that underlie the use of close elections. In view of our use of mother fixed effects, we check on the further identifying assumption that there are no omitted mother-specific trends the effects of which may load onto the variable of interest. We conduct a range of sensitivity checks including three sorts of falsification exercises and investigate heterogeneity in impact by characteristics of the child/mother and political variables including competition and decentralization.

We further estimate equations that replace mortality in equation (1) with a vector of village public goods on the one hand and a vector of individual antenatal and early postnatal health-seeking behaviors on the other. We investigate fertility and the sex of births as further outcomes. The identification strategies we use to analyze these investments and behaviors are similar and are detailed below, alongside the results.

\section{Results}

\section{A. Survival Outcomes}

Estimates of equations (1) and (2) are in Table 2. Consider effect sizes in the richest specification, which appears in column 6. Raising the share of seats held by women at the district level (women) by one standard deviation (0.0740) is estimated to result in declines in neonatal [infant] mortality of 1.5 [1.4] percentage points. This is 24 [14] percent of the mean rate in the sample, which is $6.3[9.8]$ percent and it 
TABle 2-BASELINe Results

\begin{tabular}{|c|c|c|c|c|c|c|}
\hline & $\begin{array}{c}\text { OLS } \\
(1)\end{array}$ & $\begin{array}{c}\text { OLS } \\
(2)\end{array}$ & $\begin{array}{c}\text { OLS } \\
(3)\end{array}$ & $\begin{array}{c}\text { 2SLS } \\
(4)\end{array}$ & $\begin{array}{c}\text { 2SLS } \\
(5)\end{array}$ & $\begin{array}{c}2 \text { SLS } \\
(6)\end{array}$ \\
\hline \multicolumn{7}{|l|}{ Panel A. Neonatal mortality } \\
\hline $\begin{array}{l}\text { Fraction of seats in district won } \\
\quad \text { by female politicians (women) }\end{array}$ & $\begin{array}{c}-0.0050 \\
(0.016)\end{array}$ & $\begin{array}{c}-0.0148 \\
(0.018)\end{array}$ & $\begin{array}{c}-0.0303 \\
(0.023)\end{array}$ & $\begin{array}{c}-0.1176 \\
(0.074)\end{array}$ & $\begin{array}{l}-0.1942 * * \\
(0.079)\end{array}$ & $\begin{array}{l}-0.2061 * * * \\
(0.078)\end{array}$ \\
\hline District FE & $\mathrm{x}$ & $\mathrm{x}$ & & $\mathrm{x}$ & & \\
\hline Cohort FE & $\mathrm{x}$ & $\mathrm{x}$ & $\mathrm{x}$ & $\mathrm{x}$ & $\mathrm{x}$ & $\mathrm{x}$ \\
\hline Mother FE & & & $\mathrm{x}$ & & $\mathrm{x}$ & $\mathrm{x}$ \\
\hline Controls & & & & & & $\mathrm{x}$ \\
\hline Vote margins & & & & $\begin{array}{l}\text { 3rd order } \\
\text { polynomial }\end{array}$ & $\begin{array}{l}\text { 3rd order } \\
\text { polynomial }\end{array}$ & $\begin{array}{l}\text { 3rd order } \\
\text { polynomial }\end{array}$ \\
\hline $\begin{array}{l}\text { Observations } \\
\text { Number of mothers }\end{array}$ & 95,016 & 71,498 & 71,498 & 71,498 & $\begin{array}{l}71,498 \\
18,754\end{array}$ & $\begin{array}{l}71,498 \\
18,754\end{array}$ \\
\hline
\end{tabular}

First-stage regressions. Dependent variable: Fraction of seats in the district won by female politicians

\begin{tabular}{|c|c|c|c|c|c|c|}
\hline & & & & (1) & (2) & (3) \\
\hline $\begin{array}{l}\text { Fraction of seats in district won by } \\
\text { female politicians in close } \\
\text { elections against male politicians } \\
\text { (womenclose) }\end{array}$ & & & & $\begin{array}{l}0.8939 * * * \\
(0.0714)\end{array}$ & $\begin{array}{l}0.9011^{* * * *} \\
(0.0785)\end{array}$ & $\begin{array}{l}0.8964 * * * \\
(0.0789)\end{array}$ \\
\hline $\begin{array}{l}\text { Fraction of seats in district that had } \\
\text { close elections between female } \\
\text { and male candidates (totalclose) }\end{array}$ & & & & $\begin{array}{l}-0.4303 * * * \\
(0.0528)\end{array}$ & $\begin{array}{l}-0.4514 * * * \\
(0.0559)\end{array}$ & $\begin{array}{c}-0.4495^{* * * *} \\
(0.0559)\end{array}$ \\
\hline$F$ first stage & & & & 156.27 & 131.6 & 129.1 \\
\hline & $\begin{array}{l}\text { OLS } \\
(1)\end{array}$ & $\begin{array}{l}\text { OLS } \\
(2)\end{array}$ & $\begin{array}{l}\text { OLS } \\
(3)\end{array}$ & $\begin{array}{c}2 \text { SLS } \\
(4)\end{array}$ & $\begin{array}{c}\text { 2SLS } \\
(5)\end{array}$ & $\begin{array}{c}2 \text { SLS } \\
(6)\end{array}$ \\
\hline $\begin{array}{l}\text { Panel B. Infant mortality } \\
\text { Fraction of seats in district won } \\
\quad \text { by female politicians (women) }\end{array}$ & $\begin{array}{l}0.0081 \\
(0.019)\end{array}$ & $\begin{array}{r}0.0029 \\
(0.022)\end{array}$ & $\begin{array}{r}-0.0143 \\
(0.024)\end{array}$ & $\begin{array}{c}-0.0540 \\
(0.098)\end{array}$ & $\begin{array}{c}-0.1645 \\
(0.107)\end{array}$ & $\begin{array}{l}-0.1916^{*} \\
(0.104)\end{array}$ \\
\hline District FE & $\mathrm{x}$ & $\mathrm{x}$ & & $\mathrm{x}$ & & \\
\hline Cohort FE & $\mathrm{x}$ & $\mathrm{x}$ & $\mathrm{x}$ & $\mathrm{x}$ & $\mathrm{x}$ & $\mathrm{x}$ \\
\hline $\begin{array}{l}\text { Mother FE } \\
\text { Controls }\end{array}$ & & & $\mathrm{x}$ & & $\mathrm{x}$ & $\mathrm{x}$ \\
\hline $\begin{array}{l}\text { Controls } \\
\text { Vote margins }\end{array}$ & & & & $\begin{array}{l}\text { 3rd order } \\
\text { polynomial }\end{array}$ & $\begin{array}{l}\text { 3rd order } \\
\text { polynomial }\end{array}$ & $\begin{array}{c}\mathrm{x} \\
\text { 3rd order } \\
\text { polynomial }\end{array}$ \\
\hline $\begin{array}{l}\text { Observations } \\
\text { Number of mothers }\end{array}$ & 91,169 & 68,665 & 68,665 & 68,665 & $\begin{array}{l}68,665 \\
18,003\end{array}$ & $\begin{array}{l}68,665 \\
18,003\end{array}$ \\
\hline
\end{tabular}

First-stage regressions. Dependent variable: Fraction of seats in the district won by female politicians

\begin{tabular}{|c|c|c|c|}
\hline & (1) & (2) & (3) \\
\hline $\begin{array}{l}\text { Fraction of seats in district won by } \\
\text { female politicians in close } \\
\text { elections against male politicians } \\
\text { (womenclose) }\end{array}$ & $\begin{array}{l}0.9202 * * * \\
(0.0671)\end{array}$ & $\begin{array}{l}0.9302 * * * \\
(0.0744)\end{array}$ & $\begin{array}{l}0.9255^{* * * *} \\
(0.0752)\end{array}$ \\
\hline $\begin{array}{l}\text { Fraction of seats in district that had } \\
\text { close elections between female } \\
\text { and male candidates (totalclose) }\end{array}$ & $\begin{array}{c}-0.4575 * * * \\
(0.0507)\end{array}$ & $\begin{array}{c}-0.4818 * * * \\
(0.0537)\end{array}$ & $\begin{array}{c}-0.4797 * * * \\
(0.0540)\end{array}$ \\
\hline$F$ first stage & 187.6 & 156.3 & 151.3 \\
\hline
\end{tabular}

Notes: Robust standard errors clustered at the district level are reported between parentheses. The first columns (1 and 2) show estimates with the full sample, while subsequent columns show estimates for mothers with at least two births. Close elections are defined as elections in which the winner won against the runner up by less than 3.5 percent of votes. All regressions include district and cohort fixed effects (FE); the third and fourth columns replace district FE with mother FE. Note that mother FE include or imply district FE since mothers do not migrate across districts between births (by construction: this is investigated in Section VB). All equations include state specific linear trends, district specific trends are included in Table 3. Controls at the district level include the fraction of the district population that is female, urban and SC/ST, and male and female literacy rates. Controls at the individual level include dummy variables for gender, caste, religion, birth order, rural/urban location and for whether the birth is one of a multiple birth. All regressions shown also include as a control the fraction of constituencies in the district that had close elections between women and men (totalclose).

*** Significant at the 1 percent level.

** Significant at the 5 percent level.

* Significant at the 10 percent level. 
corresponds to a 0.063 [0.048] change in the SD of neonatal [infant] mortality. Since the distribution of women is skewed (Figure A1 in the online Appendix), we consider the survival improvements brought about by electing one additional woman. The median district has nine constituencies and so nine seats. As it happens, close to 10 percent of districts in the sample have exactly nine seats and in this set the mean $(0.034)$ and median (0) share of seats held by women is very similar to the sample mean (0.036) and median (0). If one additional woman wins, the median number of seats goes from 0 to 1 and the share from 0 to $1 / 9=0.11$. If we plug this in to the estimated equations, we get even larger numbers. The predicted decline in neonatal [infant] mortality is now 2.3 [2.1] percentage points. Later we show that the effects of politician gender on infant mortality are entirely determined by its effects on neonatal mortality (Section VC).

Table 2 describes how the estimates for neonatal mortality evolve as the specification is enriched to improve identification. The OLS coefficient is small and insignificant. There is no significant change in it when the sample is restricted to mothers with at least two births in column 2, the sample that will be used in the final specification. Controlling for mother fixed effects in the OLS specification results in a larger negative coefficient but it remains poorly determined. The 2SLS coefficients are larger and, conditional upon mother fixed effects, statistically significant. The IV-fixed effects coefficient is not significantly different from the IV coefficient (column 4 versus column 5). Introducing the household and district level controls listed in notes to Table 2 makes no significant difference although the coefficient is slightly larger. ${ }^{11}$

The OLS coefficient may be biased by the endogeneity of voter preferences. Our finding that it is biased downwards is consistent with women being more likely to be elected in districts with poorer baseline health. The inclusion of mother and, implicitly, district fixed effects implies that results will not reflect fixed differences between districts, but it may be that female politicians are elected in districts with declining trends in health. The difference between the IV and OLS coefficients may also reflect a difference between the local average identified off close races and the average effect. How the local and the average impacts compare depends upon the underlying theoretical model, and our findings appear consistent with a citizen candidate model. If the cost of a close race is higher than of a nonclose race then a candidate needs a higher payoff to play, suggesting that only candidates with far apart preferences will play (Rehavi 2003). Another possibility is that women who run in close races against men are positively selected on characteristics, having overcome greater social barriers to compete on a male-dominated terrain.

In general, IV coefficients will be larger when the variable of interest is measured with error but we expect that measurement error in counting women winners in Indian elections is small. Indeed, if measurement error were important then, as this is exacerbated by differencing, we would expect attenuation of the coefficient upon introduction of mother fixed effects. Instead the coefficient is larger still, possibly

\footnotetext{
${ }^{11}$ Table 2 reports only the coefficient on the regressor of interest. Online Appendix Table A6 reports the full set of coefficients. Given that the effect we find for infant mortality is mainly capturing the effect on neonatal mortality, the extensions below will be for neonatal mortality. Parallel results for infant mortality are available on request.
} 
indicating that parents reinforce endowments in allocations across siblings, consistent with other evidence that points in this same direction (Almond and Mazumder 2013).

The first stage of the 2SLS estimates is also reported in Table 2. The instrument is powerful and the share of women who win across all elections varies proportionately with the share of women who win in close elections. ${ }^{12}$ With the share of women winners in close elections constant, the share of all women winners is negatively associated with the total share of close elections within a district since this now varies only with the share of male winners. The coefficient in the reduced form of the equation system $(1),(2)$ is -0.1847 with a standard error of 0.070 .

\section{B. Robustness Checks}

We first outline checks on the close-elections assumption (online Appendix Tables A1-A5) and then discuss robustness of the baseline specification to specification checks (Table 3; online Appendix Tables A7-A9).

The Close-Elections Assumption.-Following the initial use of the close election identification strategy in the context of close elections between Democrats and Republicans in the United States (Lee 2001), concerns have been raised that the outcomes of close elections may be biased in favor of incumbents or in favor of candidates from parties that have strategic control over the election process (Snyder 2005; Caughey and Sekhon 2011; Grimmer et al. 2011). We investigate incumbency and party affiliation in addition to other observables but find no evidence of this problem for our sample of close elections between men and women in India. A simple regression shows that the proportion of women in a district who won in a close election against a man is independent of the history of close elections in the district, the history of women being elected, the share of seats that each of eight parties contested in close elections and a host of district-time varying demographic variables (Table A1 in the online Appendix). Candidate and constituency characteristics are also independent of the gender of the winner in close elections. This includes the number of other female candidates in the constituency, whether the winner was the incumbent, the number of close elections in the past, the votes received by the winner and turnout (Table A2 in the online Appendix). These results are consistent with the gender of the winner in close elections between men and women being random.

Our estimates rely upon districts that had at least one close election between a woman and a man and the share of all births in the sample that occur in these districts is 7.45 percent. In Tables A3 and A4 in the online Appendix, we investigate whether districts that had a close election are matched on observables to districts that did not. The observables include district demographics, the share of villages with hospitals and schools, and the share of seats won by each gender in elections that were not close (online Appendix Table A3). The mean differences are small but some are significantly different from zero, which underlines the importance of our controlling

\footnotetext{
${ }^{12}$ The coefficient on the fraction of constituencies won by women in close elections against men in panel A is 0.89 , which is not significantly different from 1 . But some female politicians win in elections that are not close elections against men, some win against a man by a large margin, and others may win against another woman.
} 
TABle 3-Robustness Checks

\begin{tabular}{|c|c|c|c|c|c|c|c|c|}
\hline & (1) & (2) & (3) & (4) & (5) & (6) & (7) & (8) \\
\hline \multicolumn{9}{|c|}{ Panel A. Neonatal mortality } \\
\hline $\begin{array}{l}\text { Fraction of seats in } \\
\text { in district won by } \\
\text { female politicians }\end{array}$ & $\begin{array}{c}-0.1473^{* *} \\
(0.070)\end{array}$ & $\begin{array}{c}-0.1902 * * * \\
(0.073)\end{array}$ & $\begin{array}{c}-0.1984 * * * \\
(0.073)\end{array}$ & $\begin{array}{c}-0.1969 * * \\
(0.091)\end{array}$ & $\begin{array}{l}-0.2616^{* * * *} \\
(0.088)\end{array}$ & $\begin{array}{l}-0.2611 \text { *** } \\
(0.077)\end{array}$ & $\begin{array}{l}-0.1422 * * \\
(0.072)\end{array}$ & $\begin{array}{c}-0.2289 * * \\
(0.091)\end{array}$ \\
\hline Cohort FE & $\mathrm{x}$ & $\mathrm{x}$ & $\mathrm{x}$ & $\mathrm{x}$ & $\mathrm{x}$ & $\mathrm{x}$ & $\mathrm{x}$ & $\mathrm{x}$ \\
\hline Mother FE & $\mathrm{x}$ & $\mathrm{x}$ & $\mathrm{x}$ & $\mathrm{x}$ & $\mathrm{x}$ & $\mathrm{x}$ & $\mathrm{x}$ & $\mathrm{x}$ \\
\hline Controls & $\mathrm{x}$ & $\mathrm{x}$ & $\mathrm{x}$ & $\mathrm{x}$ & $\mathrm{x}$ & $\mathrm{x}$ & $\mathrm{x}$ & $\mathrm{x}$ \\
\hline Margins & $\begin{array}{c}\text { no } \\
\text { polynomial }\end{array}$ & $\begin{array}{c}1 \text { st order } \\
\text { polynomial }\end{array}$ & $\begin{array}{l}\text { 2nd order } \\
\text { polynomial }\end{array}$ & $\begin{array}{l}\text { 3rd order } \\
\text { polynomial }\end{array}$ & $\begin{array}{c}\text { 3rd order } \\
\text { polynomial }\end{array}$ & $\begin{array}{c}\text { 3rd order } \\
\text { polynomial }\end{array}$ & $\begin{array}{c}\text { 3rd order } \\
\text { polynomial }\end{array}$ & $\begin{array}{c}\text { 3rd order } \\
\text { polynomial }\end{array}$ \\
\hline Robustness checks & $\begin{array}{l}\text { victory } \\
\text { margin }\end{array}$ & $\begin{array}{l}\text { victory } \\
\text { margin }\end{array}$ & $\begin{array}{l}\text { victory } \\
\text { margin }\end{array}$ & $2 \%$ & $2.50 \%$ & $3 \%$ & $4 \%$ & $\begin{array}{c}\text { at least } \\
\text { one w-m ele }\end{array}$ \\
\hline Observations & 71,498 & 71,498 & 71,498 & 71,498 & 71,498 & 71,498 & 71,498 & 29,979 \\
\hline Number of mothers & 18,754 & 18,754 & 18,754 & 18,754 & 18,754 & 18,754 & 18,754 & 9,989 \\
\hline \multicolumn{9}{|c|}{ Panel B. Neonatal mortality } \\
\hline $\begin{array}{l}\text { Fraction of seats in } \\
\text { district won by } \\
\text { female politicians }\end{array}$ & $\begin{array}{c}-0.1956^{* *} \\
(0.078)\end{array}$ & $\begin{array}{l}-0.2212 * * \\
(0.086)\end{array}$ & $\begin{array}{c}-0.2091 * * * \\
(0.079)\end{array}$ & $\begin{array}{l}-0.1886^{* * *} \\
(0.076)\end{array}$ & $\begin{array}{l}-0.2001 * * * \\
(0.076)\end{array}$ & $\begin{array}{c}-0.2079 * * \\
(0.082)\end{array}$ & $\begin{array}{l}-0.1658^{* *} \\
(0.082)\end{array}$ & $\begin{array}{c}-0.1670^{* *} \\
(0.080)\end{array}$ \\
\hline Cohort FE & $\mathrm{x}$ & $\mathrm{x}$ & $\mathrm{x}$ & $\mathrm{x}$ & $\mathrm{x}$ & $\mathrm{x}$ & $\mathrm{x}$ & $\mathrm{x}$ \\
\hline Mother FE & $\mathrm{x}$ & $\mathrm{x}$ & $\mathrm{x}$ & $\mathrm{x}$ & $\mathrm{x}$ & $\mathrm{x}$ & $\mathrm{x}$ & \\
\hline Controls & $\mathrm{x}$ & $\mathrm{x}$ & $\mathrm{x}$ & $\mathrm{x}$ & $\mathrm{x}$ & $\mathrm{x}$ & $\mathrm{x}$ & $\mathrm{x}$ \\
\hline Margins & $\begin{array}{c}\text { 3rd order } \\
\text { polynomial }\end{array}$ & $\begin{array}{c}\text { 3rd order } \\
\text { polynomial }\end{array}$ & $\begin{array}{c}\text { 3rd order } \\
\text { polynomial }\end{array}$ & $\begin{array}{c}\text { 3rd order } \\
\text { polynomial }\end{array}$ & $\begin{array}{c}\text { 3rd order } \\
\text { polynomial }\end{array}$ & $\begin{array}{c}\text { 3rd order } \\
\text { polynomial }\end{array}$ & $\begin{array}{c}\text { 3rd order } \\
\text { polynomial }\end{array}$ & $\begin{array}{c}\text { 3rd order } \\
\text { polynomial }\end{array}$ \\
\hline Robustness checks & $\begin{array}{l}\text { political } \\
\text { controls }\end{array}$ & outliers & $\begin{array}{c}\text { age mother } \\
F E\end{array}$ & $\begin{array}{c}\text { mother } \\
\text { cohort } \times \\
\text { child birth } \\
y r F E\end{array}$ & quad trends & $\begin{array}{c}\text { state } \times \text { birth } \\
\text { year } \\
\text { FE }\end{array}$ & $\begin{array}{l}\text { district } \\
\text { trends }\end{array}$ & $\begin{array}{c}\text { district } \times \\
\text { mother } \\
\text { cohort FE }\end{array}$ \\
\hline Observ & 71,498 & 70,581 & 71,498 & 71,498 & 71,498 & 71,498 & 71,498 & 71,498 \\
\hline Number of mothers & 18,754 & 18,591 & 18,754 & 18,754 & 18,754 & 18,754 & 18,754 & \\
\hline
\end{tabular}

Notes: See notes to Table 2. Here we show robustness checks on the specification in column 6 of Table 2 . Columns 1-3 in panel A vary the functional form for the constituency-level victory margins, columns 4-7 vary the definition of close elections upwards and downwards from the baseline definition of a (constituency-level) vote margin that is less than 3.5 percent. Column 8 estimates the model on the sub-sample of districts that had at least one election between a woman and a man. Column 1 in panel B includes controls for the share of votes won by each of seven political parties (see the Data Appendix) and the share of seats reserved for the low caste (SC/ST) population. Column 2 removes outliers in women (see the text). Columns 3 and 4 include increasingly flexible controls for mother's age at birth. Column 5 replaces linear with quadratic state trends, column 6 with state $\times$ year dummies and column 7 adds district-specific cohort trends. Column 8 adds district-mother's birth year fixed effects.

for the fraction of seats in the district that had close elections between women and men. The share of constituencies won by each of the main political parties in India is not significantly different between close and nonclose elections (online Appendix Table A4). We nevertheless control in the regressions for the district-level seat shares of each of seven parties for the reason stated in the next section.

Electoral Variables.-Since regression discontinuity underlies the close election IV approach, we investigate parameterization of the vote margin between the winner and runner up. The coefficient of interest is not significantly altered by dropping these controls or restricting the order of the polynomial (Table 3, columns 1-3). The premise that the gender of the leader is random in a close election only holds in a small window around the point where the vote margin between the winner and the runner up is zero, but there is an efficiency-robustness trade-off in deciding the width of the window. We therefore investigate the chosen threshold for identification of close elections, varying this downwards and upwards from the selected 3.5 percent 
to include the range 2 to 4 percent. There is no significant change in the coefficient on women (columns 4-7). We restricted the sample to district-year observations (41 percent of the baseline sample) in which there was at least one election between a man and a woman as these are the observations upon which identification rests. This makes no significant difference (column 8). ${ }^{13}$

To control for the possibility that certain political parties strategically appoint women candidates more than others (Rai 2002), we condition upon the district share of seats occupied by each of seven parties. ${ }^{14}$ We also control for the district share of state assembly seats reserved for low-caste candidates to allow for the possibility that women and men compete differently for these seats. These changes do not alter the coefficient of interest (Table 3, panel B, column 1). Using the outer fence of the interquartile range, we removed outliers in women's representation above the seventy-fifth percentile. This amounts to removing the 1.45 percent of observations with women greater than 28 percent. The estimates are robust to this (Table 3, panel B, column 2).

Within-Mother Trends.-In a model with mother fixed effects, identification of calendar time effects can only come from mothers having children at different moments in time, and there is necessarily a trend in birth order and the mother's age at birth between siblings. This makes it important to isolate the effects of time-variation in women's political representation from the effects of birth-order and the age of the mother at each birth. We already control flexibly for birth order, using dummies for each order. We now introduce age at birth dummies and more flexible controls for mother's age at birth, namely, dummies for mother's cohort $\times$ child cohort (Table 3, columns 3-4, panel B). For a given year of birth of the mother, the year of birth of the child implies the age of the mother at birth. Since the estimated equations already include fixed effects for the child's birth year, this is equivalent to controlling for fixed effects in the age of the mother at birth and allowing their impact to vary by the birth cohort of the mother. Controls for mother's age at birth are also important in correcting for the fact that retrospective fertility (and mortality) data grow increasingly unrepresentative of mother's age as we go further back in time (Rindfuss, Palmore, and Bumpass 1982). See the Data Appendix.

Other Unobserved Trends.-We investigated controls for unobservable trends in general. The estimates in Table 2 are conditional upon state linear trends. We now include, in sequence, state-specific quadratic trends, state $\times$ year dummies, district-specific trends, and district $\times$ mother's cohort dummies (columns 5-8, panel B of Table 3). The last is important because a potential problem with using only district fixed effects is that different cohorts of mothers in different districts, having been exposed to different income and health conditions, are more or less

\footnotetext{
${ }^{13}$ In principle we could implement a sharp regression discontinuity using districts in which there was exactly one election between a man and a woman but in practice we do not have enough within-mother variation in this.

${ }^{14}$ Following Besley and Burgess (2002), seven party groups are constructed: Congress, Hard Left, Soft Left, Janata, Hindu, Regional parties, and Independents coupled with other small parties (these are the parties in A4 where Independent and other are separated; also see the Data Appendix).
} 
TABle 4-Timing of the EfFects ANd FALSIFICATION EXercise

\begin{tabular}{|c|c|c|c|c|c|}
\hline \multirow[b]{2}{*}{$\begin{array}{l}\text { Child's age when } \\
\text { politician was in power }\end{array}$} & \multicolumn{2}{|c|}{ Neonatal mortality } & \multirow[b]{2}{*}{$\begin{array}{l}\text { Child's age when } \\
\text { politician was in power }\end{array}$} & \multicolumn{2}{|c|}{ Neonatal mortality } \\
\hline & Coefficient & SE & & Coefficient & SE \\
\hline \multicolumn{6}{|c|}{ Coefficient: Fraction of seats in the district won by female politicians } \\
\hline-3 & -0.0983 & 0.0900 & 4 & -0.0114 & 0.0760 \\
\hline-2 & $-0.2257 * *$ & 0.0990 & 5 & 0.0676 & 0.0700 \\
\hline-1 & $-0.2061 * * *$ & 0.0780 & 6 & 0.0247 & 0.0860 \\
\hline 0 & $-0.1975 * *$ & 0.0840 & 7 & 0.0200 & 0.0860 \\
\hline 1 & -0.0417 & 0.0830 & 8 & 0.0410 & 0.0950 \\
\hline 2 & -0.0338 & 0.0820 & 9 & -0.0801 & 0.0940 \\
\hline 3 & -0.0121 & 0.0810 & & & \\
\hline
\end{tabular}

Notes: See notes to Table 2. The baseline specification in column 6 of Table 2 uses the first lag $(-1)$ of the gender mix of politicians at the district level because neonatal mortality is largely determined by the fetal environment and birth conditions. That equation is re-estimated here without a lag to investigate the existence of contemporaneous effects and with two additional lags. We also investigate leads (1 to 9) of politician gender as a placebo (see the text).

likely to have children with lower survival chances. ${ }^{15}$ Again, as we condition upon fixed effects for the child's birth year, this effectively allows for district-varying trends in the age of the mother at birth. The estimates are robust to these fairly powerful controls.

Lags.- Since interventions motivated by politicians may operate with a lag, we investigated lags as far back as the third year before birth; see Table 4. Some persistence is built in by virtue of politicians typically holding office for five years, as then politicians elected two years before a child is born will on average be in power the year before and the year the child is born. ${ }^{16}$ We find that the gender composition of politicians in the two years before birth and in the birth year $(t-2$, $t-1, t)$ has a similar sized significant coefficient but the share of women in power more than two years before the index birth has no impact. In India most women have a birth within two years of marriage, so this particular pattern of fading is consistent with politicians targeting women at risk of conception (newly married women) with interventions such as prenatal care information, immunization or nutrition and this showing an impact on offspring born one or two years later.

Placebos.-To further mitigate concerns that we are capturing omitted trends, we implemented placebos. First, we modeled the neonatal mortality risk of cohorts born in $t$ as a function of future politician gender $(t+1$ to $t+9)$; these coefficients are all essentially zero (Table 4). Second, we used the sample of mothers that moved to the current location a year or more after the birth of their youngest child so their births are effectively matched to politicians that they were never exposed to. Again, the coefficient on women is small and insignificant (online Appendix

\footnotetext{
${ }^{15}$ See Bhalotra (2010) on the importance of mother's birth year conditions for offspring health and see Kudamatsu (2012) for a related discussion in the context of mother fixed effects estimation of the impact of democratization on mortality.

${ }^{16}$ Politicians in power at $t-5$ will tend to exit before or in the birth year $t$, politicians in power in $t-4$ will tend to exit before or in $t+1$, and so on.
} 
Table A8, column 1). However, there is a problem with this test which is that we do not know whether the previous location was in the same district or in a different one, and this adds noise to the estimates. A third placebo was run using as an outcome, the height of mothers. Since adult height is largely determined in early childhood (Bozzoli, Deaton, and Quintana-Domeque 2009), we expect politicians in the birth year of the child to have no impact on the height of the mother, and this is what we see (Table A9 in the online Appendix).

Migration.-The estimates in Table 2 are on the sample of mothers that have had all their births in their current place of residence. This is a strong restriction. We relax it to include only children who were born in the current place of residence of the mother. In order to investigate the extent of any selectivity in migration, we also estimate the model with no restrictions. The coefficient of interest grows smaller as we successively lift restrictions on the sample but it remains significant and within two standard errors of the baseline coefficient (Table A8 in the online Appendix). ${ }^{17}$ This puts aside any concern that our selection of a nonmigrant mother sample is either creating a bias or producing results that may be altogether unrepresentative.

\section{Extensions}

The results discussed here are displayed in Tables 5 and 6 .

Birth Order.-If one of the ways that women politicians influence health outcomes is through information campaigns then we may expect exposure to women politicians to have a larger impact on outcomes for first births. This is what we find (Table 5, columns 1-2, panel A). Aizer and Currie (2004) adduce a similar distinction between first and higher order births in attempting to isolate the role of information diffusion in women's social networks. In principle, facilities constructed around the birth of a first child will also tend to persist within mother so that they are available to her further births even if the share of women in government has changed. However, there is widespread absenteeism of medical practitioners from public health facilities (Muralidharan et al. 2011) so, in contrast to information, the effective availability of facilities will tend to vary within mother.

Heterogeneity in Household Status.-Since child mortality is concentrated amongst the poor, our finding of impacts of politician gender on mortality establish the progressiveness of women in state assemblies, in contradiction of debates that currently block the institution of quotas for women at this level (see Section II). We investigated this further by allowing the effects of politician gender to differ by the caste, wealth and rural/urban location of the family (Table 5). The coefficients are larger for lower castes, consistent with their greater "treatability." They exhibit an inverted U-shape in wealth, with the smallest effects apparent for the poorest

\footnotetext{
${ }^{17}$ The smaller coefficients are consistent with migrant women and children being matched in the data to politicians who had no influence on them because at least some of the migrants (those who moved district) had moved away from their domain.
} 
Table 5-Heterogeneity in Impact: Individual Variables. Neonatal Mortality

\begin{tabular}{|c|c|c|c|c|c|c|c|}
\hline & (1) & (2) & (3) & (4) & (5) & (6) & (7) \\
\hline \multicolumn{8}{|l|}{ Panel A } \\
\hline $\begin{array}{l}\text { Fraction of seats in } \\
\text { district won by female } \\
\text { politicians (women) }\end{array}$ & $\begin{array}{c}-0.2528^{*} \\
(0.152)\end{array}$ & $\begin{array}{c}-0.0760 \\
(0.081)\end{array}$ & $\begin{array}{c}-0.1432 * \\
(0.079)\end{array}$ & $\begin{array}{l}-0.5677 * * \\
(0.253)\end{array}$ & $\begin{array}{c}-0.2648^{*} \\
(0.143)\end{array}$ & $\begin{array}{r}-0.1715 \\
(0.160)\end{array}$ & $\begin{array}{c}-0.1911 \\
(0.142)\end{array}$ \\
\hline Sample & First child & $\begin{array}{l}\text { Subsequent } \\
\text { children }\end{array}$ & Rural & Urban & $S C / S T$ & $O B C$ & Higher caste \\
\hline Observations & 18,562 & 52,936 & 56,273 & 15,225 & 21,827 & 23,134 & 26,537 \\
\hline Number of mothers & & & 14,401 & 4,353 & 5,416 & 6,085 & 7,253 \\
\hline Panel B & (1) & (2) & (3) & (4) & $(5)$ & $(6)$ & \\
\hline $\begin{array}{l}\text { Fraction of seats in } \\
\text { district won by female } \\
\text { politicians (women) }\end{array}$ & $\begin{array}{c}-0.1469 \\
(0.138)\end{array}$ & $\begin{array}{l}-0.2199 * * \\
(0.112)\end{array}$ & $\begin{array}{l}-0.3228^{* *} \\
(0.153)\end{array}$ & $\begin{array}{c}-0.2050 \\
(0.156)\end{array}$ & $\begin{array}{l}-0.3366^{* *} \\
(0.159)\end{array}$ & $\begin{array}{c}-0.2458^{*} \\
(0.143)\end{array}$ & \\
\hline Sample & Girls & Boys & Girls & Girls & Girls & Boys & \\
\hline Control & & & $\begin{array}{l}\text { Gender first } \\
\text { child }\end{array}$ & $\begin{array}{l}\text { Gender first } \\
\text { child }\end{array}$ & $\begin{array}{l}\text { Gender } \\
\text { siblings }\end{array}$ & $\begin{array}{l}\text { Gender } \\
\text { siblings }\end{array}$ & \\
\hline Observations & 27,886 & 31,871 & 17,025 & 18,699 & 17,025 & 18,699 & \\
\hline Number of mothers & 9,845 & 11,797 & 6,278 & 7,199 & 6,278 & 7,199 & \\
\hline Panel C & (1) & (2) & (3) & & & & \\
\hline $\begin{array}{l}\text { Fraction of seats in } \\
\text { district won by female } \\
\text { politicians (women) }\end{array}$ & $\begin{array}{c}-0.0703 \\
(0.179)\end{array}$ & $\begin{array}{l}-0.3494 * * * \\
(0.131)\end{array}$ & $\begin{array}{c}-0.1219 \\
(0.170)\end{array}$ & & & & \\
\hline Sample & Wealth bottom & Wealth mid & Wealth top & & & & \\
\hline Control & $20 \%$ & $40 \%$ & $40 \%$ & & & & \\
\hline Observations & 19,217 & 30,823 & 20,558 & & & & \\
\hline Number of mothers & 4,728 & 7,967 & 5,862 & & & & \\
\hline
\end{tabular}

Notes: See notes to Table 2. The controls are those in the baseline model, see Table 2, column 6. Columns in the top panel separate first and higher birth orders, rural and urban births, SC/ST, OBC, and higher caste births. In panel B the columns separate girls and boys, births in households in the bottom $20 \%$ of the wealth distribution, the mid 40 percent, and the top 40 percent. We do not use mother fixed effects in the first two columns since a mother has only one first-born child by definition.

20 percent of households. A likely explanation of this is that the productivity of public intervention is contingent upon private inputs and that women in the poorest households are harder to "treat" because they have lower stocks of health before birth or because they are less likely to take up publicly provided prenatal care. It may also be that wealth is correlated with education which, in turn, is correlated with preferences for health and with the ability to access and process relevant information. ${ }^{18} \mathrm{We}$ also investigated differences by the caste of politicians. We find no difference in impact: the coefficients differ by about half a standard error (online Appendix Table A8). $\cdot 19$

Gender-Specific Impacts.-Earlier studies suggest that as women's power in decision making within the household increases marginal gains for girls exceed those

\footnotetext{
${ }^{18}$ The rates of of neonatal and infant mortality in the higher status groups are not small. In the high-caste group, the means are close to 5.2 and 8.1 percent and in the top- 40 percent of the wealth distribution they are 4.9 and 7.6 percent.

${ }^{19}$ This result stands in contrast to Clots-Figueras (2011) who finds that redistributive policy choices are driven by low-caste women (see Section I). The difference may arise from our focus upon reproductive and child health (which women of all social groups may be motivated to improve-refer to Campbell 2004 cited in Section I), but our results are not strictly comparable since we analyze individual outcomes while the earlier study analyzes state-level aggregates.
} 
Table 6-Heterogeneity in Impact: Political Variables. Neonatal Mortality

\begin{tabular}{|c|c|c|c|c|c|}
\hline & (1) & (2) & (3) & (4) & \\
\hline \multicolumn{6}{|l|}{ Panel A } \\
\hline $\begin{array}{l}\text { Fraction of seats in district won by female } \\
\text { politicians (women) }\end{array}$ & $\begin{array}{l}-0.2043 * * \\
(0.083)\end{array}$ & $\begin{array}{l}-0.2241 * * * \\
(0.079)\end{array}$ & $\begin{array}{l}-0.2347 * * \\
(0.091)\end{array}$ & & \\
\hline $\begin{array}{l}\text { Women interacted with a dummy for years } \\
\text { after } 1993\end{array}$ & $\begin{array}{c}-0.0118 \\
(0.119)\end{array}$ & & & & \\
\hline $\begin{array}{l}\text { Women interacted with political competition } \\
\text { index }\end{array}$ & & $\begin{array}{r}0.0597 \\
(0.060)\end{array}$ & & & \\
\hline $\begin{array}{l}\text { Women interacted with dummy for female } \\
\text { chief minister }\end{array}$ & & & $\begin{array}{l}-0.8425^{* * * *} \\
(0.205)\end{array}$ & & \\
\hline $\begin{array}{l}\text { Women belonging to the same party as the } \\
\text { chief minister }\end{array}$ & & & & $\begin{array}{l}-0.2109^{* *} \\
(0.092)\end{array}$ & \\
\hline $\begin{array}{l}\text { Women belonging to a different party from the } \\
\text { chief minister }\end{array}$ & & & & $\begin{array}{l}-0.1995^{* *} \\
(0.085)\end{array}$ & \\
\hline $\begin{array}{l}p \text {-value joint significance of women and } \\
\text { interacted terms }\end{array}$ & 0.0255 & 0.0162 & 0.000 & & \\
\hline Observations & 71,498 & 71,498 & 52,474 & 71,498 & \\
\hline Number of mothers & 18,754 & 18,754 & 15,664 & 18,754 & \\
\hline & $(1)$ & $(2)$ & (3) & (4) & $(5)$ \\
\hline $\begin{array}{l}\text { Fraction of seats in district won by female } \\
\text { politicians (women) }\end{array}$ & $\begin{array}{l}-0.1943 * * \\
(0.079)\end{array}$ & $\begin{array}{l}-0.1895 * * \\
(0.080)\end{array}$ & $\begin{array}{l}-0.2014 * * \\
(0.081)\end{array}$ & $\begin{array}{l}-0.2116 * * \\
(0.091)\end{array}$ & $\begin{array}{l}-0.2837 * * * \\
(0.109)\end{array}$ \\
\hline Women interacted with turnout & $\begin{array}{c}-0.0313 \\
(0.066)\end{array}$ & & & & \\
\hline Women interacted with female turnout & & $\begin{array}{r}-0.0355 \\
(0.074)\end{array}$ & & & \\
\hline Women interacted with female/male turnout ratio & & & $\begin{array}{r}-0.0265 \\
(0.080)\end{array}$ & & \\
\hline Women interacted with newspaper circulation & & & & $\begin{array}{c}-0.1310 \\
(0.205)\end{array}$ & \\
\hline $\begin{array}{l}\text { Women interacted with newspaper circulation } \\
\text { English }\end{array}$ & & & & & $\begin{array}{c}0.0199 \\
(0.119)\end{array}$ \\
\hline $\begin{array}{l}\text { Women interacted with newspaper circulation } \\
\text { Hindi }\end{array}$ & & & & & $\begin{array}{c}0.1390 \\
(0.214)\end{array}$ \\
\hline $\begin{array}{l}\text { Women interacted with newspaper circulation } \\
\text { Regional }\end{array}$ & & & & & $\begin{array}{r}-0.1547 \\
(0.291)\end{array}$ \\
\hline $\begin{array}{l}p \text {-value joint significance of women and } \\
\text { interacted terms }\end{array}$ & 0.0468 & 0.0095 & 0.0378 & 0.0568 & 0.0731 \\
\hline Observations & 71,498 & 69,306 & 69,306 & 69,507 & 52,644 \\
\hline Number of mothers & 18,754 & 18,589 & 18,589 & 18,258 & 15,639 \\
\hline
\end{tabular}

Notes: See notes to Table 2. The controls are those in the baseline model, column 6 in Table 2. In panel A, column 1 we interact a post-1993 dummy with the variable of interest (women). In column 2, we interact the variable of interest with the Besley and Burgess (2002) index of political competition. In column 3, we interact the variable of interest with a dummy for whether the chief minister was a woman. In column 4 , we create variables denoting the share of female politicians that do and do not belong to the same political party as the chief minister. In panel B, columns 1, 2, and 3, we interact with turnout, female turnout, and the ratio of male to female turnout. In column 4, we interact with newspaper circulation (Besley and Burgess 2002), and in column 5 we interact with newspaper circulation by language (Besley and Burgess 2002). Political competition, turnout and newspaper circulation are converted to $z$-scores before they are included in the model.

for boys (e.g., Duflo 2003, Thomas 1990). So, if politician identity influences policy outcomes then it is plausible that women politicians make a larger difference for girls, for example, by campaigning against son preference. So we investigated differences by child gender (Table 5). Using the baseline specification, we find slightly larger point estimates for boys, but the difference is not statistically significant. We 
probed this result by including in the model proxies for son preference. First we include a dummy for the sex of the first-born child, as previous research shows that this is quasi-random and has a discernible impact on the tendency for parents to exercise son preference (e.g., Bhalotra and Cochrane 2010). The coefficient for girls is now much larger than that for boys and statistically significant, in favor of our motivating hypothesis. However it remains insignificantly different form the coefficient for boys. We also display results using controls for the sex composition of the entire sibship surviving to the birth of the index child (for instance, one boy, one girl, a girl and a boy, and so on). The results are similar to those for the more parsimonious indicator. Note that these estimates are for the sample of children of second or higher birth order. Since controlling for the exercise of son preference does raise the point estimate for girls, we reran the baseline model which pools gender (Table 2 column 6) with these controls. The point estimate increases to -0.23 and -0.24 respectively which is insignificantly different from the baseline -0.21 .

Pre/post Devolution.-The 1993 constitutional amendment described in Section II devolved control over the implementation of development programs to the panchayat level, and this included aspects of health provision such as drinking water and immunization delivered through the Integrated Child Development Services program. We therefore allow for a weakening of the influence of politicians in state assemblies postdevolution. The estimated effect is 10 percent larger (in absolute value) after 1993 but not significantly different (Table 6, column 1, panel A). ${ }^{20}$ This tells us that women's political representation at the state level mattered through the three decades in our sample, and their power was not substantially eroded upon the empowerment of village councils.

Heterogeneity by Political Variables.-Previous work has shown that political competition disciplines politicians, making them more responsive to the needs of citizens (Besley and Burgess 2002) but there is no evidence of whether there is any effective interaction between political competition and political identity. If male and female politicians were perfect substitutes then we would expect to observe better policy outcomes in areas with strong political competition but not as a function of the gender of the leader. However if men and women having "separate spheres" of influence driven by their different preferences, competition may enhance domainspecific gender differences in policy outcomes. ${ }^{21}$ To investigate this, we interact party competition with the share of women politicians. As in Besley and Burgess (2002), we also interact turnout and newspaper circulation with the share of women politicians. The interaction terms are poorly determined but the point estimates are sizeable (Table 6). They indicate that turnout and news circulation (especially in the

\footnotetext{
${ }^{20}$ Following Iyer et al. (2012), we created a postreservation dummy that varies at the state $\times$ year level reflecting the state-specific implementation of the village level reform. Interactions with this dummy are similarly insignificant.

${ }^{21}$ There are other possibilities. If women's preferences for health are a "luxury," they may be overridden in competitive conditions. If women are marginal voters, women's preferences may hold greater sway under competition. If, as lay evidence suggests, women politicians receive more newspaper coverage than their male counterparts then the discipline flowing from increased newspaper circulation may result in greater effectiveness amongst women relative to men in government.
} 
regional language, as found in Besley and Burgess 2002) tend to enhance the policy influence of women, while party competition tends to lower it.

We also investigated the relevance of the gender and party of the chief minister to allow, for instance, that legislators are more likely to receive funds for their constituencies or have their voice heard if their preferences are more closely aligned with those of the chief minister. We find that belonging to the chief minister's party does not alter the impact of women legislators. However, when the chief minister is a woman, there is a large and significant increase in the effectiveness of women legislators (Table 6). We conducted a further interaction (not shown) with political parties classified as left and right leaning and other, but could identify no significant difference in the effectiveness of women by their party affiliation. These results underline that we identify gender rather than party effects.

Postneonatal Mortality.-We estimated the model for postneonatal mortality and found no effects of politician gender (Table A10 in the online Appendix) ${ }^{22}$ The most likely explanation of this is that the postneonatal mortality estimates are biased by endogenous selection into postneonatal exposure to mortality risk-children only enter this sample if they have survived the neonatal period, and we have seen that neonatal survival is dependent upon politician gender. However the estimates for neonatal and infant mortality are unbiased (the selection issue does not arise since these indicators are defined for all children exposed from birth). The fact that the neonatal and infant mortality estimates are of similar size suggests that reductions in neonatal mortality account for almost all of the infant mortality reduction flowing from increases in women's representation.

This is consistent with the tighter identification of neonatal mortality with public health investments in women (maternal health, breastfeeding, place of delivery). As children age into the postneonatal period, they are exposed to a more diverse set of household-level influences including income, nutrition, and aspects of parenting behavior like hygiene. It becomes harder to attribute improvements in postneonatal health to public provision and this presumably weakens politician incentives. Also, there is growing evidence that health interventions are more productive the earlier in childhood they are made (Almond and Currie 2011; Bhalotra and Venkataramani 2013): this too rationalizes investments that improve health in the first month (neonatal) as more productive than investments that improve health after (post-neonatal).23

Fertility.-By virtue of using mother fixed effects we have already accounted for endogenous variation in the composition of births. We now investigate the impact

\footnotetext{
${ }^{22}$ Mortality in the first month of life is neonatal and between the second and twelfth month is postneonatal. Infant mortality is the sum of these. Mortality risk declines sharply with age, and neonatal mortality contributes two-thirds of infant deaths. Amongst children who died before the age of 5 in our sample, 50 percent died before the age of one month (neonatal), 29 percent between one month and one year (postneonatal infant) and the remaining 21 percent of deaths occurred between the ages of one and five years. The risk of death for children who survive to the age of five is considerably smaller. Since the presence of women politicians has a mortality-deterring effect, survivors at the margin are negatively selected (see for instance, Bozzoli, Deaton, and Quintana-Domeque (2009) on the relative roles of selection and "treatment").

${ }^{23}$ We also investigated under-5 mortality and mortality rates up until age 14 (online Appendix Table A11). The coefficients are consistently negative but statistically insignificant. The selection and attribution arguments above apply a fortiori here.
} 
of politician gender on the probability that a child is born, and the sex of the child conditional upon birth, instrumenting with the outcome of close elections as before. As we have the entire fertility history of each mother, we expanded the data so that for every woman there is an observation for every year in which she is exposed to the risk of birth (starting with her age at marriage and stopping at age 49 or the date of interview). We find no significant change in the probability of a birth.

Having established that the probability of a further birth (conditional upon the last observed) is not endogenous, we can proceed to estimate child sex conditional upon birth. We find that the probability that a birth is female is increasing in the share of women politicians (online Appendix Table A12). A ready explanation of this would be that women politicians have been more committed to controlling female feticide, although we were unable to nail this down. ${ }^{24}$

Note that to the extent that women politicians lower female feticide this will create a mechanical increase in fertility which may be balancing out a decline in fertility flowing from the decline in neonatal mortality induced by raising women's representation.

\section{Channels}

In this section, we investigate the mechanisms underlying our finding that neonatal mortality responds to female political representation. We analyze the influence of women's representaton on a range of indicators of antenatal and postnatal care at the mother level and health infrastructure at the village level.

\section{A. Individual Indicators of Antenatal and Postnatal Care}

We investigated prenatal and early postnatal health-seeking behaviors that are known to impact upon early life mortality. ${ }^{25}$ These data are available for births that occur in the four years preceding the survey date (1994-1995 to 1998-1999). There are siblings in this sample (for 15.3 percent of mothers) but they are characterized by short intervening birth intervals and given the evidence that a short preceding birth interval compromises the health of a child (e.g., Bhalotra and van Soest 2008), this is a selected sample. So, while we use the close-elections instrument as before, instead of mother fixed effects, we use fixed effects for finely defined mother-groups, an approach similar to that taken in Kudamatsu (2012). We construct fixed effects for groups defined on a multidimensional space of mother traits, namely height (above/below mean), education (above/below primary), caste (SC,

\footnotetext{
${ }^{24}$ To test this hypothesis, we divided the sample at 1985 , because ultrasound scanners started to be imported in 1987 and thereafter widely used for prenatal sex detection and it is only after the mid-80s that there is a significant trend departure of the sex ratio at birth from the biologically normal level (Bhalotra and Cochrane 2010). Our expectation was that we would see a positive impact of female political representation on the female-male ratio at birth after and only after 1985 . However the post- 85 coefficients are imprecise and we cannot reject the hypothesis that they are equal before and after 1985.

${ }^{25}$ Since the samples we use for estimation of equations for survival and for health inputs are constrained to be different, we cannot conduct an accounting exercise measuring the contributions of the inputs to neonatal mortality but the inputs we consider exhibit the expected correlations with neonatal and infant survival.
} 
Table 7-Health Seeking Behaviors

\begin{tabular}{|c|c|c|c|c|c|c|c|c|}
\hline & \multicolumn{2}{|c|}{$\begin{array}{c}\text { Number of } \\
\text { antenatal visits }\end{array}$} & \multicolumn{2}{|c|}{$\begin{array}{l}\text { Iron and folic } \\
\text { supplements }\end{array}$} & \multicolumn{2}{|c|}{$\begin{array}{l}\text { Tetanus injection } \\
\text { in pregnancy }\end{array}$} & \multicolumn{2}{|c|}{$\begin{array}{l}\text { Breastfed } \\
\text { first } 24 \mathrm{hrs}\end{array}$} \\
\hline & (1) & (2) & (3) & (4) & (5) & (6) & (7) & (8) \\
\hline \multicolumn{9}{|l|}{ Panel A } \\
\hline $\begin{array}{l}\text { Fraction of seats in district } \\
\text { won by female } \\
\text { politicians (women) }\end{array}$ & $\begin{array}{l}3.6524 * * \\
(1.783)\end{array}$ & $\begin{array}{l}2.7745^{*} \\
(1.662)\end{array}$ & $\begin{array}{l}1.0663 * * * \\
(0.364)\end{array}$ & $\begin{array}{l}0.9518 * * \\
(0.429)\end{array}$ & $\begin{array}{c}0.1798 \\
(0.320)\end{array}$ & $\begin{array}{c}0.3113 \\
(0.376)\end{array}$ & $\begin{array}{l}1.2758 * * * \\
(0.462)\end{array}$ & $\begin{array}{l}1.3406^{* *} \\
(0.535)\end{array}$ \\
\hline District FE & $\mathrm{x}$ & $\mathrm{x}$ & $\mathrm{x}$ & $\mathrm{x}$ & $\mathrm{x}$ & $\mathrm{x}$ & $\mathrm{x}$ & $\mathrm{x}$ \\
\hline Cohort FE & $\mathrm{x}$ & $\mathrm{x}$ & $\mathrm{x}$ & $\mathrm{x}$ & $\mathrm{x}$ & $\mathrm{x}$ & $\mathrm{x}$ & $\mathrm{x}$ \\
\hline Mother group FE & & $\mathrm{x}$ & & $\mathrm{x}$ & & $\mathrm{x}$ & & $\mathrm{x}$ \\
\hline F first stage & 155.001 & 124.482 & 164.951 & 131.19 & 164.401 & 130.846 & 167.418 & 132.767 \\
\hline \multirow[t]{3}{*}{ Observations } & 7,448 & 7,448 & 8,429 & 8,429 & 8,383 & 8,383 & 8,062 & 8,062 \\
\hline & \multicolumn{2}{|c|}{$\begin{array}{l}\text { Delivery } \\
\text { at home }\end{array}$} & \multicolumn{2}{|c|}{$\begin{array}{l}\text { Delivery at government } \\
\text { institution }\end{array}$} & \multicolumn{2}{|c|}{$\begin{array}{l}\text { Delivery at private } \\
\text { institution }\end{array}$} & & \\
\hline & (1) & (2) & (3) & (4) & (5) & (6) & & \\
\hline \multicolumn{9}{|l|}{ Panel B } \\
\hline $\begin{array}{l}\text { Fraction of seats in district } \\
\text { won by female } \\
\text { politicians (women) }\end{array}$ & $\begin{array}{l}-0.8698^{* *} \\
(0.433)\end{array}$ & $\begin{array}{l}-0.8768 * \\
(0.522)\end{array}$ & $\begin{array}{l}1.0344 * * * \\
(0.346)\end{array}$ & $\begin{array}{l}1.0904 * * * \\
(0.394)\end{array}$ & $\begin{array}{c}-0.1646 \\
(0.344)\end{array}$ & $\begin{array}{c}-0.2136 \\
(0.350)\end{array}$ & & \\
\hline District FE & $\mathrm{x}$ & $\mathrm{x}$ & $\mathrm{x}$ & $\mathrm{x}$ & $\mathrm{x}$ & $\mathrm{x}$ & & \\
\hline Cohort FE & $\mathrm{x}$ & $\mathrm{x}$ & $\mathrm{x}$ & $\mathrm{x}$ & $\mathrm{x}$ & $\mathrm{x}$ & & \\
\hline Mother group FE & & $\mathrm{x}$ & & $\mathrm{x}$ & & $\mathrm{x}$ & & \\
\hline F first stage & 164.382 & 130.572 & 164.382 & 130.572 & 164.382 & 130.572 & & \\
\hline Observations & 8,408 & 8,408 & 8,408 & 8,408 & 8,408 & 8,408 & & \\
\hline
\end{tabular}

Notes: See notes to Table 2. As in Table 2, women is instrumented with womenclose. Means of the dependent variables are in Table 1. Mother group FE are defined in the text, they are FE defined over multiple dimensions of mother-level observables.

ST, OBC, or high caste), urban/rural location and the birth year of the mother ${ }^{26}$ and include these along with district fixed effects. The estimated equation system otherwise looks similar to (1) and (2).27

The results are in Table 7 and the mean and SD of each dependent variable is in Table 1A. As in Table 2, OLS estimates (not shown) are smaller than the IV estimates and tend to be insignificant. The table displays 2SLS estimates with and without the quasi-mother fixed effects. Here we discuss the richer specification and present effects flowing from a 10 percentage point increase in women's representation which, we explained above, is the approximate change in share associated with moving the number of women politicians elected in the median district from 0 to 1 .

Antenatal Care, Iron, and Tetanus.-The Indian government defines a complete course of antenatal care as including at least three antenatal visits, a three-month supply of iron tablets and two tetanus injections. Only 37 percent of women in our sample achieve a complete course. We find that women's political representation

\footnotetext{
${ }^{26}$ This generates about 3,000 fixed effects in a sample of just under 19,000 mothers.

${ }^{27}$ The samples used in this and the following section are different from the samples used to analyze mortality. We have checked that the first stage is still very powerful; $F$-statistics and reduced form equations available on request.
} 
increases the number of antenatal visits a woman makes by 0.28 , which is 12 percent of the mean. It raises the probability that iron supplements are taken by about 10 percentage points, relative to a mean of 57 percent. This is important given the high prevalence of anemia amongst Indian mothers (NFHS data) and the fact that it is a risk factor for low birth weight offspring and child survival (Bhalotra and Rawlings (2010). The probability that a woman has at least one tetanus injection during pregnancy (which is important in lowering the risk of neonatal tetanus) is increasing in women but not significantly.

Breastfeeding.-Women's political representation raises the probability of early breastfeeding by 13.4 percentage points, which is a 28 percent increase. Breastfeeding has been shown to influence the cognitive and emotional development of children (Del Bono and Rabe 2012). Although the vast majority of Indian women breastfeed and 77 percent of children are being breastfed at 20-23 months (UNICEF indicators), there are cultural inhibitions to breastfeeding immediately after birth and only 48 percent of Indian women in our sample initiate breastfeeding in the first 24 hours. This is when the benefits of breastfeeding are greatest, lowering the risk of contracting infectious diseases such as diarrhea and pneumonia and, thereby, lowering neonatal mortality risk (Jones et al. 2003).

Place of Birth.- Some 69 percent of births to Indian women in our sample occur at home, while the remaining 31 percent are distributed equally between public and private facilities. ${ }^{28}$ Since home births are typically unattended by professionals, they generate neonatal survival risks that can be averted in the presence of birth attendants trained in the management of sepsis (septicemia, meningitis, pneumonia); see Bang et al. (1999). We find that a 10 percentage point increase in women's political representation lowers home deliveries by 8.8 percentage points. Moreover, there is evidence that this represents a shift of births into government hospitals: the same increase in women raises the probability of giving birth in a government facility by 11 percentage points while there is no significant change in the probability of giving birth in a private facility. Contrast this with the impact of a 10 percent increase in state income: this similarly lowers home deliveries (by a more modest 1.1 percentage points) but this arises entirely from a shift towards private sector deliveries; there is no change in the share of births in government hospitals (Bhalotra 2010). This suggests that putting women at the helm leads to improved access to government hospitals, consistent with the results in the next section.

\section{B. Village Public Goods}

We now investigate how women's political representation influences tangible supply side investments. For this we use the underused village facilities survey of the NFHS to look at rural infrastructure choices. Facility is an indicator for a specified

\footnotetext{
${ }^{28}$ The share of home births is higher in rural areas, at 78 percent, compared with 33 percent in urban areas. The share of the residual births in public and private facilities is similar in rural and urban areas.
} 
facility in village $v$ in district $d$ in year $t$. Instrumenting for the district share of women as before, we estimate this linear equation system using 2SLS:

(3) facility $_{v d t}=\alpha_{d}+\theta_{t}+\beta$ women $_{d t-1}+\sum_{j=1}^{N} \partial_{1 j} I_{j d t} \times F\left(m_{j d t}\right)$

$$
+\sum_{j=1}^{N} \partial_{2 j} I_{j d t}+\lambda \text { totalclose } e_{d t-1}+Z_{d t} \mu+\varepsilon_{i m d t}
$$

(4) women $_{d t}=\chi_{d}+\omega_{t}+\tau$ womenclose $_{d t}+\sum_{j=1}^{N} \partial_{1 j} I_{j d t} \times F\left(m_{j d t}\right)$

$$
+\sum_{j=1}^{N} \partial_{2 j} I_{j d t}+\psi \text { totalclose }_{d t}+Z_{d t} \pi+\varepsilon_{\text {imdt }} .
$$

The estimation sample contains 1,591 villages (in the 246 districts), 76 percent of which are surveyed in 1998 and the rest in 1997. ${ }^{29}$ As in the baseline specification for mortality, women is measured in the year before birth. We find that village public facilities vary significantly with the share of women politicians in the district in which the village lies (Table 8). The estimates are sharp and consistent across categories. A 10 percentage point increase in women raises the probability that the village has a primary health center, a community health center, a government dispensary and a government hospital by $0.22,0.19,0.18$, and 0.057 respectively.

With a view to identifying the sorts of village infrastructure that male politicians are more likely to provide, we ran the regressions reported in panel B of Table 8 . A 10 percentage point increase in the share of women politicians (which decreases the share of male politicians) significantly lowers the probability that the village has a bank. We also observe sizeable negative coefficients on indicators for post offices and telephone facilities, although these are poorly determined. ${ }^{30}$ In sum, the evidence suggests that women politicians are significantly more likely to invest in the public health infrastructure while men are more likely to invest in the financial and telecommunications infrastructure. This defends our initial hypothesis. While we control for voter (and mother) characteristics, we are unable to control for politician characteristics. Therefore, some part of the relationships that we identify may flow from women who win in close [political] races against men being positively selected. However our finding that women favor health over financial infrastructure suggests that preferences do play a role.

\footnotetext{
${ }^{29}$ The reported results are conditional upon year and district fixed effects, but the coefficient of interest is insensitive to dropping the district effects.

${ }^{30}$ So as to investigate the impact of these policy choices on state income, we used state-level panel data, instrumenting with close elections. We find no impact of the share of women in state assemblies on state income, by which measure it would appear that raising the political representation of women is a cost-effective way of improving public health.
} 
Table 8-Village Public Goods

\begin{tabular}{|c|c|c|c|c|c|}
\hline Variables & $\begin{array}{c}\text { Primary } \\
\text { health subcenter } \\
\text { (1) }\end{array}$ & $\begin{array}{c}\text { Primary } \\
\text { health center } \\
\text { (2) }\end{array}$ & $\begin{array}{l}\text { Community } \\
\text { health center } \\
\text { (3) }\end{array}$ & $\begin{array}{l}\text { Government } \\
\text { dispensary } \\
\text { (4) }\end{array}$ & $\begin{array}{l}\text { Government } \\
\text { hospital } \\
(5)\end{array}$ \\
\hline \multicolumn{6}{|l|}{ Panel A } \\
\hline $\begin{array}{l}\text { Fraction of seats in } \\
\text { district won by } \\
\text { female politicians } \\
\text { (women) }\end{array}$ & $\begin{array}{c}3.4769 \\
(2.215)\end{array}$ & $\begin{array}{l}2.2365 * * \\
(1.120)\end{array}$ & $\begin{array}{l}1.8871^{* * *} \\
(0.849)\end{array}$ & $\begin{array}{l}1.7857 * * \\
(0.900)\end{array}$ & $\begin{array}{l}0.5682^{*} \\
(0.311)\end{array}$ \\
\hline Year dummies & $\mathrm{x}$ & $\mathrm{x}$ & $\mathrm{x}$ & $\mathrm{x}$ & $\mathrm{x}$ \\
\hline District dummies & $\mathrm{x}$ & $\mathrm{x}$ & $\mathrm{x}$ & $\mathrm{x}$ & $\mathrm{x}$ \\
\hline $\begin{array}{l}\text { Observations } \\
R^{2}\end{array}$ & $\begin{array}{l}1,558 \\
0.326\end{array}$ & $\begin{array}{l}1,558 \\
0.342\end{array}$ & $\begin{array}{l}1,558 \\
0.354\end{array}$ & $\begin{array}{l}1,558 \\
0.370\end{array}$ & $\begin{array}{l}1,558 \\
0.210\end{array}$ \\
\hline Variables & $\begin{array}{l}\text { Electricity } \\
\text { (1) }\end{array}$ & $\begin{array}{c}\text { Bank } \\
(2)\end{array}$ & $\begin{array}{l}\text { Post } \\
\text { office } \\
(3)\end{array}$ & $\begin{array}{c}\text { Telegraph } \\
\text { (4) }\end{array}$ & $\begin{array}{l}\text { STD (telephone) } \\
\text { booth } \\
(5)\end{array}$ \\
\hline \multicolumn{6}{|l|}{ Panel B } \\
\hline $\begin{array}{l}\text { Fraction of seats in } \\
\text { district won by } \\
\text { female politicians } \\
\text { (women) }\end{array}$ & $\begin{array}{c}0.9865 \\
(1.225)\end{array}$ & $\begin{array}{c}-2.4616^{*} \\
(1.494)\end{array}$ & $\begin{array}{c}-2.1704 \\
(2.218)\end{array}$ & $\begin{array}{c}0.6037 \\
(1.241)\end{array}$ & $\begin{array}{c}-0.9293 \\
(1.589)\end{array}$ \\
\hline Year dummies & $\mathrm{x}$ & $\mathrm{x}$ & $\mathrm{x}$ & $\mathrm{x}$ & $\mathrm{x}$ \\
\hline District dummies & $\mathrm{x}$ & $\mathrm{x}$ & $\mathrm{x}$ & $\mathrm{x}$ & $\mathrm{x}$ \\
\hline Observations & 1,558 & 1,558 & 1,558 & 1,558 & 1,558 \\
\hline$R^{2}$ & 0.455 & 0.280 & 0.306 & 0.231 & 0.238 \\
\hline
\end{tabular}

Notes: See notes to Table 2. As in Table 2, women is instrumented with womenclose. All regressions include districts and year dummies and population controls. The means of the dependent variables are in Table 1 . The $F$-statistic of the first-stage regressions is 45.973 .

\section{Discussion}

We have identified significant impacts of women's political representation on a range of indicators of prenatal care, immunization, place of birth and breastfeeding, and on different dimensions of the village-level health infrastructure. This indicates the sorts of things that politicians do towards improving public health services, suggesting the mechanisms underlying our finding that childhood mortality rates respond to women's representation.

We argue that the improvements in health-seeking behaviors are consistent with both infrastructure and information improvements. An advantage of studying outcomes (i.e., Does a child survive? Does a mother receive iron supplements? etc.) rather than direct inputs such as infrastructure or expenditure is not only that they reflect the effectiveness of inputs but also that they capture complementary policy influences including information campaigns. Information is important in the health domain. For example, Miller (2008) finds that door-to-door campaigns advocating home hygiene played a critical role in the steep decline in infant mortality in American history, and the uptake of publicly provided health services in India appears to be limited because people do not fully recognize the benefits (Banerjee et al. 2010). Information may act in either of two ways: to encourage the uptake of public services (such as antenatal care), or to encourage private inputs (such as 
breastfeeding). Since breastfeeding does not require public infrastructure, the identified impact of women's representation on breastfeeding directly indicates a role for information campaigns. Also, the survey data we use asked women what inhibited them in making antenatal care visits and as many as 60 percent said that they did not think it was necessary, which suggests the potential for information campaigns to generate large improvements in the use of antenatal care. ${ }^{31}$ As discussed in Section VC, our finding that the largest impact of women's representation is on the first birth of a mother is also consistent with a role for information.

Although it is useful to look at timing, we cannot discriminate between information and infrastructure mechanisms based upon timing alone. While building new facilities may take more than a year, it is often the case in rural India that an existing building is brought into use so that in principle infrastructure can be raised within the space of a year. Moreover, politicians can act fairly rapidly to influence staffing and supplies in facilities or to discourage absenteeism among health providers (see Chaudhury et al. 2006, Muralidharan et al. 2011) by improving monitoring and incentives. In these ways politicians may improve the effectiveness of facilities (and hence mortality rates) without any construction of infrastructure. ${ }^{32}$

It is difficult to specify the trade-off involved in (randomly) replacing a woman with a man in political office without having a full specification of the influence of each on the entire portfolio of policies, but we noted earlier that raising the share of women relative to men leads to more public health infrastructure and less rural banking infrastructure. The premise for favoring an increase in women's political participation must be that this balances the representation of women's interests against those of men.

\section{Conclusions}

We investigated whether women politicians invest more in antenatal care and early child health because women incur the costs of reproduction and replacement fertility and they make greater investments in the early life health of their offspring. We identify significant causal impacts of women's political representation on neonatal survival, uptake of reproductive and postnatal care, and the village level public health infrastructure. The estimated impacts are large, suggesting that raising women's political representation may be an effective and novel way of improving public health delivery in developing countries. Women's representation at the state level is a live issue in the Indian Parliament today, and quotas for women in government have been established in more than 100 countries in the last 15 years (Dahlerup and Francisco 2005). Our findings are relevant to debates concerning political reservations, especially in view of recent evidence that women holding office paves the way for competitively determined participation of women in politics (Beaman et

\footnotetext{
${ }^{31}$ Access to publicly provided care is clearly relevant too since the next highest frequency, 16 percent, was recorded for it costing too much. Only 3.5 percent said it was too inconvenient or too far and 1.6 percent said it was because a health worker did not visit.

${ }^{32}$ There may be complementarities in the outcomes we look at and between provision of facilities and information, for example, mothers who give birth in a facility rather than at home are more likely to receive information and encouragement to initiate breastfeeding soon after birth.
} 
al. 2009; Bhavnani 2009; Deininger, Jin, and Nagarajan 2011; Casas-Arce and Saiz 2011; Bhalotra, Clots-Figueras, and Iyer 2013).

\section{REFERENCES}

Aizer, Anna, and Janet Currie. 2004. "Networks or neighborhoods? Correlations in the use of publicly funded maternity care in California." Journal of Public Economics 88 (12): 2573-85.

-Alesina, Alberto, and Eliana La Ferrara. 2005. "Preference for redistribution in the land of opportunities." Journal of Public Economics 89 (5-6): 897-931.

-Alexander, Richard D. 1974. "The Evolution of Social Behavior." Annual Review of Ecology and Systematics 5: 325-83.

Almond, Douglas, and Janet Currie. 2011. "Killing Me Softly: The Fetal Origins Hypothesis.” Journal of Economic Perspectives (25): 153-72.

-Almond, Douglas, and Bhashkar Mazumder. 2013. "Fetal Origins and Parental Responses." Annual Review of Economics 5: 37-56.

Andreoni, James, and Lise Vesterlund. 2001. "Which is the Fair Sex? Gender Differences in Altruism." Quarterly Journal of Economics 116 (1): 293-312.

Angrist, Joshua D., and Jörn-Steffen Pischke. 2008. Mostly Harmless Econometrics: An Empiricist's Companion. Princeton: Princeton University Press.

Banerjee, Abhijit, Angus Deaton, and Esther Duflo. 2003. "Health Care Delivery in rural Rajasthan." http://economics.mit.edu/files/771.

Banerjee, Abhijit, Esther Duflo, Rachel Glennerster, and Dhruva Kothari. 2010. "Improving immunization coverage in rural India: clustered randomized controlled evaluation of immunization campaigns with and without incentives." British Medical Journal 340: c2220.

-Bang, Abhay T., Rani A. Bang, Sanjay B. Baitule, M. Hanimi Reddy, and Mahesh D. Deshmukh. 1999. "Effect of home-based neonatal care and management of sepsis on neonatal mortality: field trial in rural India." Lancet 354 (9194): 1955-61.

-Beaman, Lori, Raghabendra Chattopadhya, Esther Duflo, Rohini Pande, and Petia Topalova. 2009. "Powerful Women: Does Exposure Reduce Bias?" Quarterly Journal of Economics 124 (4): 1497-1540.

Beaman, Lori, Esther Duflo, Rohini Pande, and Petia Topalova. 2007. Powerful Women Politicians, Gender Bias, And Policy-Making In Rural India. The State of the World's Children Background Paper. United Nations Children's Fund (UNICEF). New York, December.

-Bertrand, Marianne, Esther Duflo, and Sendhil Mullainathan. 2004. "How Much Can We Trust Difference-In-Differences Estimators?" Quarterly Journal of Economics 119 (1): 249-75.

Besley, Timothy, and Robin Burgess. 2002. "The Political Economy of Government Responsiveness: Theory and Evidence from India.” Quarterly Journal of Economics 117 (4): 1415-51.

Besley, Timothy, and Anne Case. 2000. "Unnatural Experiments? Estimating the Incidence of Endogenous Policies.” Economic Journal 110 (467): 672-94.

Besley, Timothy, and Anne Case. 2003. "Political Institutions and Policy Choices: Evidence from the United States." Journal of Economic Literature 41 (1): 7-73.

Besley, Timothy, and Stephen Coate. 1997. "An Economic Model of Representative Democracy." Quarterly Journal of Economics 112 (1): 85-114.

Besley, Timothy, and Masayuki Kudamatsu. 2006. "Health and Democracy." American Economic Review Papers and Proceedings 96 (2): 313-18.

Bhalotra, Sonia. 2007. "Spending to save? State health expenditure and infant mortality in India." Health Economics 16 (9): 911-28.

Bhalotra, Sonia. 2010. "Fatal fluctuations: Cyclicality in infant mortality in India." Journal of Development Economics 93 (1): 7-19.

Bhalotra, Sonia, and Irma Clots-Figueras. 2014. "Health and the Political Agency of Women: Dataset." American Economic Journal: Economic Policy. http://dx.doi.org/10.1257/pol.6.2.164.

Bhalotra, Sonia, Irma Clots-Figueras, and Lakshmi Iyer. 2013. "Path-Breakers: How Does Women's Political Participation Respond to Electoral Success?" Harvard Business School Working Paper 14-305.

Bhalotra, Sonia, and Tom Cochrane. 2010. "Where Have All the Young Girls Gone? Identification of Sex Selection in India.” Institute for the Study of Labor (IZA) Discussion Paper 5381.

Bhalotra, Sonia, and Samantha B. Rawlings. 2010. "Intergenerational persistence in health in developing countries: The penalty of gender inequality?” Journal of Public Economics 95 (3-4): 286-99. 
Bhalotra, Sonia, and Arthur V. Soest. 2008. "Birth-spacing, fertility and neonatal mortality in India: Dynamics, frailty and fecundity." Journal of Econometrics 143 (2): 274-90.

Bhalotra, Sonia, and Atheendar Venkataramani. 2013. "Shadows of the Captain of the Men of Death: Early Life Health Interventions, Human Capital Investments, and Institutions." http://ssrn.com/ abstract $=1940725$.

Bhavnani, Rikhil R. 2009. "Do Electoral Quotas Work after They Are Withdrawn? Evidence from a Natural Experiment in India." American Political Science Review 103 (1): 23-35.

- Black, Robert E., Saul S. Morris, and Jennifer Bryce. 2003. "Where and why are 10 million children dying every year?" Lancet 361 (9376): 2226-34.

-Bozolli, Carlos, Angus Deaton, and Climent Quintana-Domeque. 2009. "Adult Height and Childhood Disease." Demography 46 (4): 647-69.

Campbell, Rosie. 2004. "Gender, Ideology and Issue Preference: Is There such a Thing as a Political Women's Interest in Britain?" British Journal of Politics and International Relations 6 (1): 20-46.

Casas-Arce, Pablo, and Albert Saiz. 2011. "Women and Power: Unwilling, Ineffective, or Held Back?" Institute for the Study of Labor (IZA) Discussion Paper 5645.

Caughey, Devin, and Jasjeet S. Sekhon 2011. "Elections and the Regression-Discontinuity Design: Lessons From Close U.S. House Races, 1942-2008.” Political Analysis 19 (4): 385-408.

Chattopadhay, Raghabendra, and Esther Duflo. 2004. "Women as Policy Makers: Evidence from a Randomized Policy Experiment in India." Econometrica 72 (5): 1409-43.

-Chaudhury, Nazmul, Jeffrey Hammer, Michael Kremer, Karthik Muralidharan, and F. Halsey Rogers. 2006. "Missing in Action: Teacher and Health Worker Absence in Developing Countries." Journal of Economic Perspectives 20 (1): 91-116.

-Clots-Figueras, Irma. 2011. "Women in politics: Evidence from the Indian States." Journal of Public Economics 95 (7-8): 664-90.

-Clots-Figueras, Irma. 2012. "Are Female Leaders Good for Education? Evidence from India." American Economic Journal: Applied Economics 4 (1): 212-44.

-Cutler, David, Angus Deaton, and Adriana Lleras-Muney. 2006. "The Determinants of Mortality." Journal of Economic Perspectives 20 (3): 97-120.

Dahlerup, Drude, and Josefa Francisco. 2005. Gender, Governance and Democracy: Women in Politics. Isis International-Manila and Women and Gender Institute (WAGI) Manila.

Das, Jishnu, and Jeffrey Hammer. 2007. "Money for nothing: The dire straits of medical practice in Delhi, India." Journal of Development Economics 83 (1): 1-36.

Das Gupta, Monica. 2005. "Public Health in India: Dangerous Neglect." Economic and Political Weekly XL (49): 5159-65.

Dehejia, Rajeev, and Adriana Lleras-Muney. 2004. “Booms, Busts and Babies' Health.” Quarterly Journal of Economics 119 (3): 1091-1130.

Deininger, Klaus, Songqing Jin, and Hari K. Nagarajan. 2011. "Can Political Reservation Improve Female Empowerment? Evidence from Local Panchayat Elections in Rural India." Unpublished.

Del Bono, Emilia, and Birgitta Rabe. 2012. "Breastfeeding and child cognitive outcomes: evidence from a hospital-based breastfeeding support policy." Institute for Social and Economic Research (ISER) Working Paper 2012-29.

Downs, Anthony. 1957. An Economic Theory of Democracy. New York: Harper Collins.

Duflo, Esther. 2003. "Grandmothers and Granddaughters: Old-Age Pensions and Intrahousehold Allocation in South Africa." World Bank Economic Review 17 (1): 1-25.

-Edlund, Lena, Laila Haider, and Rohini Pande. 2005. "Unmarried Parenthood and Redistributive Politics." Journal of the European Economic Association 3 (1): 95-119.

-Edlund, Lena, and Rohini Pande. 2002. "Why Have Women Become Left-Wing? The Political Gender Gap and the Decline in Marriage." Quarterly Journal of Economics 117 (3): 917-61.

-Filmer, Deon, Jeffery S. Hammer, and Lant H. Pritchett. 2000. "Weak Links in the Chain: A Diagnosis of Health Policy in Poor Countries." World Bank Research Observer 15 (2): 199-224.

-Filmer, Deon, and Lant Pritchett. 1999. "The impact of public spending on health: does money matter?" Social Science and Medicine 49 (10): 1309-23.

Franceschet, Susan, Mona L. Krook, and Jennifer M. Piscopo. 2009. "The Impact of Gender Quotas: A Research Agenda." MPSA Conference Paper. Chicago: Midwest Political Science Association National Conference.

Grimmer, Justin, Eitan Hersh, Brain Feinstein, and Daniel Carpenter. 2011. "Are Close Elections Random?" http://scholar.harvard.edu/files/feinstein/files/rdd.pdf.

- Hoddinott, John, and Lawrence Haddad. 1995. "Does Female Income Share Influence Household Expenditures? Evidence from Côte d'Ivoire." Oxford Bulletin of Economics and Statistics 57 (1): 77-96. 
International Institute for Population Sciences and ORC Macro. 2000. National Family Health Survey (NFHS-2) 1998-99: India. International Institute for Population Sciences (IIPS). Mumbai, October.

Iyer, Lakshmi, Anandi Mani, Prachi Mishra, and Petia Topalova. 2011. "The Power of Political Voice: Women's Political Representation and Crime in India." American Economic Journal: Applied Economics 4 (4): 165-93.

-Jones, Gareth, Richard W. Steketee, Robert E. Black, Zulfiqa A. Bhutta, and Saul S. Morris. 2003. "The Bellagio Child Survival Study 'How Many Child Deaths Can We Prevent This Year?"' Lancet 362 (9377): 65-71.

Kiefer, Philip, and Stuti Khemani. 2003. “Democracy, Public Expenditures and the Poor.” World Bank Policy Research Working Paper 3164.

Kudamatsu, Masayuki. 2012. "Has Democratization Reduced Infant Mortality in Sub-Saharan Africa? Evidence from Micro Data." Journal of the European Economic Association 10 (6): 1294-1317.

-Lee, David S. 2001. "Randomized experiments from non-random selection in U.S. House elections." Journal of Econometrics 142 (2): 675-97.

Levitt, Steven D. 1996. "How Do Senators Vote? Disentangling the Role of Voter Preferences, Party Affiliation and Senator Ideology." American Economic Review 86 (3): 425-41.

Lundberg, Shelly J., Robert A. Pollak, and Terence J. Wales. 1997. "Do Husbands and Wives Pool Their Resources? Evidence From the United Kingdom Child Benefit.” Journal of Human Resources 32 (3): 463-80.

Miller, Grant. 2008. "Women's Suffrage, Political Responsiveness, and Child Survival in American History.” Quarterly Journal of Economics 123 (3): 1287-1327.

Miller, Grant, and B. Piedad Urdinola. 2010. "Cyclicality, Mortality, and the Value of Time: The Case of Coffee Price Fluctuations and Child Survival in Colombia.” Journal of Political Economy 118 (1): 113-55.

Mishra, Ramesh C. 2000. Role of Women in Legislatures in India: A Study. New Delhi: Anmol Publications.

Muralidharan, Karthik, Michael Kremer, Nazmul Chaudhury, Jeffrey Hammer, and F. Halsey Rogers. 2011. "Is There a Doctor in the House? Medical Worker Absence in India." http://scholar.harvard.edu/files/kremer/files/is_there_a_doctor_in_the_house_-_12_april_2011.pdf.

-Nickell, Stephen. 1981. "Biases in Dynamic Models with Fixed Effects." Econometrica 49 (6): 1417-26.

-Osborne, Martin J., and Al Slivinski. 1996. "A Model of Political Competition with Citizen-Candidates." Quarterly Journal of Economics 111 (1): 65-96.

-Oswald, Andrew J., and Nattavudh Powdthavee. 2010. "Daughters and Left-Wing Voting." Review of Economics and Statistics 92 (2): 213-27.

Peters, David H., Abdo S. Yazbeck, Rashmi R. Sharma, G. N. V. Ramana, Lant H. Pritchett, and Adam Wagstaff. 2002. Better Health Systems for India's Poor. Human Development Network. Washington, DC: World Bank.

Pettersson-Lidbom, Per. 2001. "Do Parties Matter for Fiscal Policy Choices? A Regression-Discontinuity Approach.” http://people.su.se/ pepet/Party.pdf.

Rai, Shirin. 2002. "Class, Caste and Gender - Women in Parliament in India." International IDEA, Women in Parliament, Stockholm. http://www.cccindia.co/corecentre/Database/Docs/DocFiles/cs_ india.pdf.

Rao, M. Govinda, and Nirvikar Singh. 1998. "The Assignment of Taxes and Expenditures in India." http://citeseerx.ist.psu.edu/viewdoc/download?rep=rep1\&type=pdf\&doi=10.1.1.226.4806.

Rehavi, M. 2003. "Sex and Politics: Do Female Legislators Affect State Spending?" Unpublished.

Rindfuss, Ronald R., James A. Palmore, and Larry L. Bumpass. 1982. "Selectivity and the Analysis of Birth Intervals from Survey Data.’ Asia Pacific Census Forum 8 (3): 5-16.

Snyder, Jason. 2005. "Detecting Manipulation in U.S. House Elections." Unpublished.

-Squires, Judith. 1996. “Quotas for Women: Fair Representation?” Parliamentary Affairs 49 (1): 71-88.

- Thomas, Duncan. 1990. "Intra-Household Resource Allocation: An Inferential Approach.” Journal of Human Resources 25 (4): 635-64.

Thomas, Sue, and Susan Welch. 1991. "The Impact of Gender on Activities and Priorities of State Legislators." Western Political Quarterly 44 (2): 445-56.

-Warner, Rebecca L., and Brent S. Steel. 1999. "Child Rearing as a Mechanism for Social Change: The Relationship of Child Gender to Parents' Commitment to Gender Equity." Gender and Society 13 (4): 503-17.

-Washington, Ebonya L. 2008. "Female Socialization: How Daughters Affect Their Legislator Fathers' Voting on Women's Issues." American Economic Review 98 (1): 311-32. 